\title{
14. RADIOLARIANS FROM THE SOUTHWEST PACIFIC 1
}

\author{
J.-P. Caulet, Laboratoire de Géologie du Muséum National d'Histoire Naturelle²
}

\begin{abstract}
Radiolarians are very rare in all Leg 90 sites. They are relatively more frequent only in Neogene sediments from Sites 586 and 594, and in Eocene sediments at Site 592. In this chapter radiolarian abundances are recorded as comparative percentages for 92 Neogene morphotypes at Site 586B. Relative abundances only are estimated at Sites 592 and 594, where preservation is poor to moderate. A tentative correlation of radiolarian events at Hole 586B and Site 594 shows that only a few species can be found in both tropical and subantarctic areas.

New evolutionary lineages are proposed. 1. Middle Miocene eucyrtids like Eucyrtidium teuscheri group evolved into a widespread species (E. teuscheri teuscheri) ranging from middle Miocene to Holocene and a temperate species $(E$. teuscheri orthoporus) ranging from middle Miocene to early Pleistocene. 2. Phormostichoartus pitomorphus appears to be a temperate descendant of the cosmopolitan $P$. fistula and disappears in early Pleistocene time. 3 . The discovery of Lamprocyrtis daniellae $\mathrm{n} . \mathrm{sp}$. calls into question the lineage $L$. heteroporos $\rightarrow L$. nigriniae. 4 . The evolution of Lamprocyclas maritalis from an ancestor group ( $L$. aff. maritalis) is located in the early part of the Pterocanium prismatium Zone.
\end{abstract}

\section{INTRODUCTION}

Because only carbonate-rich sediments deposited in relatively shallow environments were cored during Leg 90 , radiolarians are generally absent or few in the material recovered. Moderately to well-preserved radiolarian assemblages occur throughout the sequences cored at equatorial Hole $586 \mathrm{~B}\left(00^{\circ} 29.84^{\prime} \mathrm{S}, 158^{\circ} 29.89^{\prime} \mathrm{E}\right.$; water depth from rig floor, $2217 \mathrm{~m}$ ) and at the subantarctic Site $594\left(45^{\circ} 31.41^{\prime} \mathrm{S}, 174^{\circ} 56.88^{\prime} \mathrm{E}\right.$; water depth 1204 m). At Site $592\left(36^{\circ} 28.40^{\prime} \mathrm{S}, 165^{\circ} 26.53^{\prime} \mathrm{E}\right.$; water depth $1098 \mathrm{~m}$ ), radiolarians occur in small amounts, but only in upper Eocene sediments. Of particular interest at this site is a fine, complete boundary section between the Eocene and the Oligocene in Cores 592-36 and 592-37.

Hole 586B, with relatively well preserved specimens, provides a good sequence of late Neogene assemblages deposited in tropical shallow waters. Thus, it is important to verify if the radiolarian zonation is applicable to sediments accumulated below areas of high productivity and above the carbonate compensation depth (CCD).

Site 594 lies in the subantarctic water mass immediately south of the Subtropical Convergence. Thus the relative abundance of radiolarians allows studies of late Cenozoic paleoceanographic and paleoclimatic history. Moreover, Site 594 is important for establishing a radiolarian stratigraphy for upper Neogene sediments deposited during periods of temperate climate.

\section{PROCEDURES}

Except for Hole 592, where sampling for radiolarian studies was restricted to the Eocene/Oligocene boundary, one to five samples were taken from each core, acidified to remove carbonate, sieved at $50 \mu \mathrm{m}$, and the coarse fraction strewn on slides according to conventional methods.

\footnotetext{
${ }^{1}$ Kennett, J. P., von der Borch, C. C., et al., Init. Repts. DSDP, 90: Washington (U.S. Govt, Printing Office).

2 Address: Laboratoire de Géologie du Muséum National d'Histoire Naturelle, 43, rue de Buffon, 75005 Paris, France.
}

Relative abundances are recorded in two ways. At Sites 592 and 594 , where radiolarian occurrences are sporadic and preservation poor to moderate, four grades of abundance are used to indicate the abundance percentage of a taxon relative to the total assemblage of a strewn slide. These abundance grades and their symbols are explained in Table 2, later. At Hole 586B, where Cenozoic sediments contain well-preserved radiolarians, percentage estimates were used. The density of radiolarians on a slide having been estimated, the percentage of unbroken shells, which can be recognized at species level, was calculated by counting well-preserved individuals among 800 radiolarian whole specimens plus fragments. Next, 92 taxons were searched for and counted, if present, over the whole surface of the slide, and their abundance percentages were calculated relative to the number of unbroken shells. Radiolarian density is of the same order as in the study of Riedel and Westberg, 1982. The procedure developed by Westberg and Riedel (1982) for evaluating the stratigraphic reliability of upper and lower limits of taxa was applied at Hole 586B.

The radiolarian zones used in this paper for the Pliocene and Miocene at Site 586B are similar to the chronozones defined by Riedel and Sanfilippo (1978). The Quaternary zones are those defined by Caulet (1979).

At Site 594, the antarctic/subantarctic zonation proposed by Chen (1975) is not used because antarctic species occur so sporadically throughout the sequence and because some morphotypes are completely absent. Because equatorial and high-latitude assemblages are mixed, parts of both preexisting equatorial and antarctic event scales have been employed. Artostrobiidae are abundant, and the sequence of events proposed by Nigrini (1977) was successfully used and compared to occurrences of tropical and antarctic morphotypes. The Quaternary zones are those defined by Caulet (1982) for mid-latitude assemblages.

As part of the investigation of Leg 90 radiolarians, the data are supported by detailed radiolarian documentation from many Marion Dufresne (MD) piston cores from the South Indian Ocean region. These include the cores:

MD 73028: $49^{\circ} 25.9^{\prime} \mathrm{S}, 61^{\circ} 46.5^{\prime} \mathrm{E}, 2650 \mathrm{~m}$ water depth.

MD 75071: $38^{\circ} 24.9^{\prime} \mathrm{S}, 69^{\circ} 34.2^{\prime} \mathrm{E}, 4305 \mathrm{~m}$ water depth.

MD 75072: $37^{\circ} 55.7^{\prime} \mathrm{S}, 67^{\circ} 58.6^{\prime} \mathrm{E}, 4260 \mathrm{~m}$ water depth.

MD 75075: $34^{\circ} 23.4^{\prime} \mathrm{S}, 66^{\circ} 26.7^{\prime} \mathrm{E}, 4725 \mathrm{~m}$ water depth.

MD AET $75002: 34^{\circ} 34.5^{\prime} \mathrm{S}, 63^{\circ} 31.0^{\prime} \mathrm{E}, 4147 \mathrm{~m}$ water depth.

MD $77157: 4^{\circ} 48.2^{\prime} \mathrm{S}, 90^{\circ} 02.3^{\prime} \mathrm{E}, 4833 \mathrm{~m}$ water depth.

Detailed studies of these cores have been published (Caulet, 1977, 1982) or are in preparation.

\section{RADIOLARIANS IN HOLES 586B, 592, AND 594}

In Tables 1, 2, and 3 radiolarian occurrences are summarized for those stratigraphic intervals in which there are identifiable radiolarians. 
Table 1. Relative abundance (\%) of radiolarians from Hole 586B.

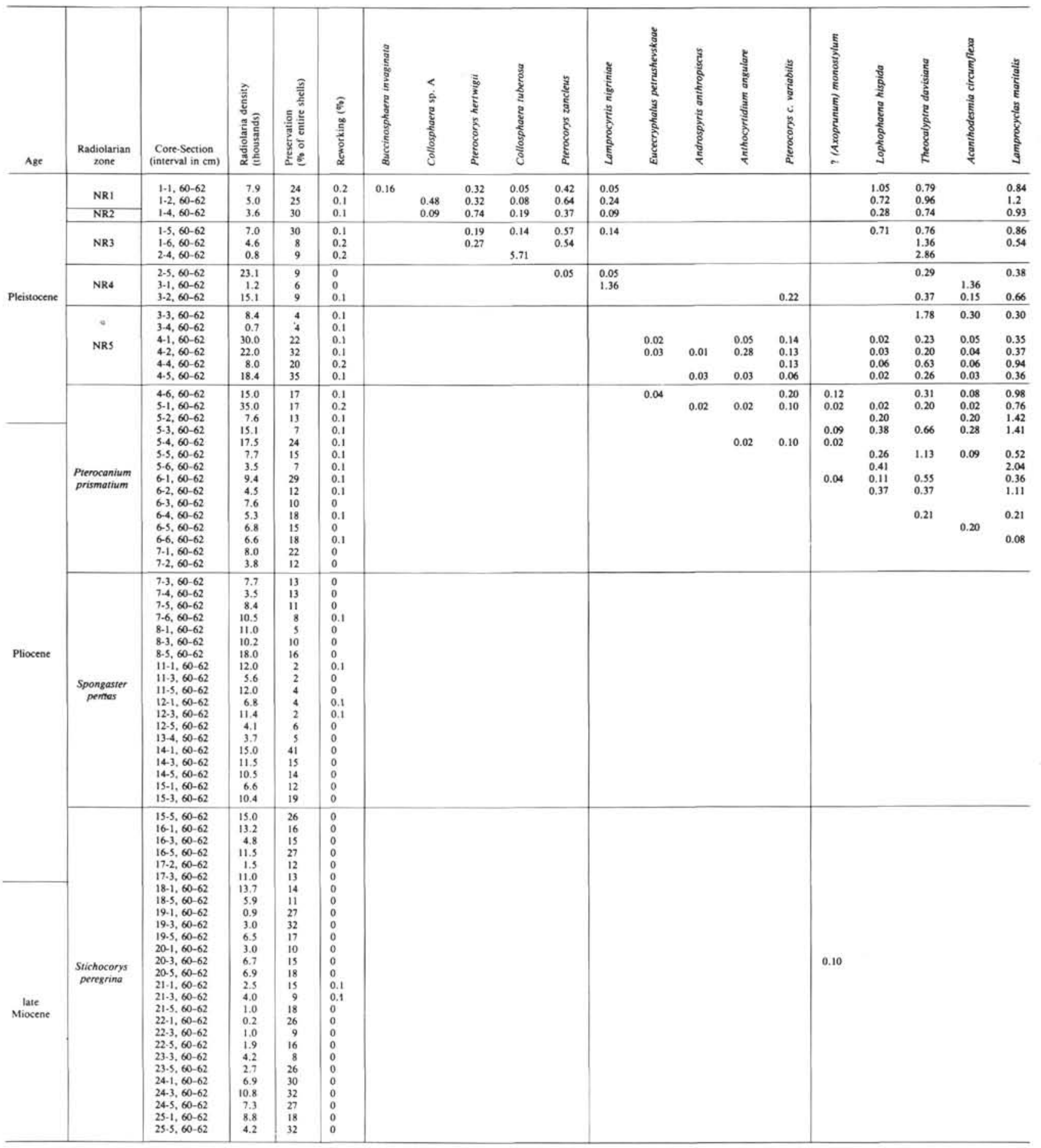

Note: Quantitative approach outlined in procedures, In the body of the table numbers indicate abundance in percent of total unbroken radiolarians on the slide. The following samples were barren of radiolarians: $5868-2-1$. $60-62 \mathrm{~cm} ; 586 \mathrm{~B}-2-2,60-62 \mathrm{~cm}, 586 \mathrm{~B}-2-3,60-62 \mathrm{~cm} ; 586 \mathrm{~B}-2 \cdot 6,60-62 \mathrm{~cm} ; 586 \mathrm{~B}-3-5,60-62 \mathrm{~cm} ; 582 \mathrm{~B}-3 .-6,60-62 \mathrm{~cm}$.

\section{Hole 586B}

Radiolarians are rare and are poorly to moderately preserved in the samples from Core 586B-1 through 586B-25. A limited number of samples are barren (see Table 1), and there is some evidence of reworking.

The late and early Pleistocene faunas are well preserved but mid-Pleistocene Radiolaria are rare to absent and frequently dissolved. Zone NR1 (= Buccinosphaera invaginata Zone) yielded a rich fauna with the zone fossil, identified in Sample 586B-1-2, 60-62 cm. Zone NR2 extends from Samples 586B-1-2, 60-62 cm to 586B-1-4, $60-62 \mathrm{~cm}$. Zone NR3 occurs between the first occurrence of Collosphaera tuberosa in Sample 586B-2-4, 60$62 \mathrm{~cm}$ and the last occurrence of Stylatractus universus in Sample 586B-1-5, 60-62 cm. 
Table 1. (Continued).

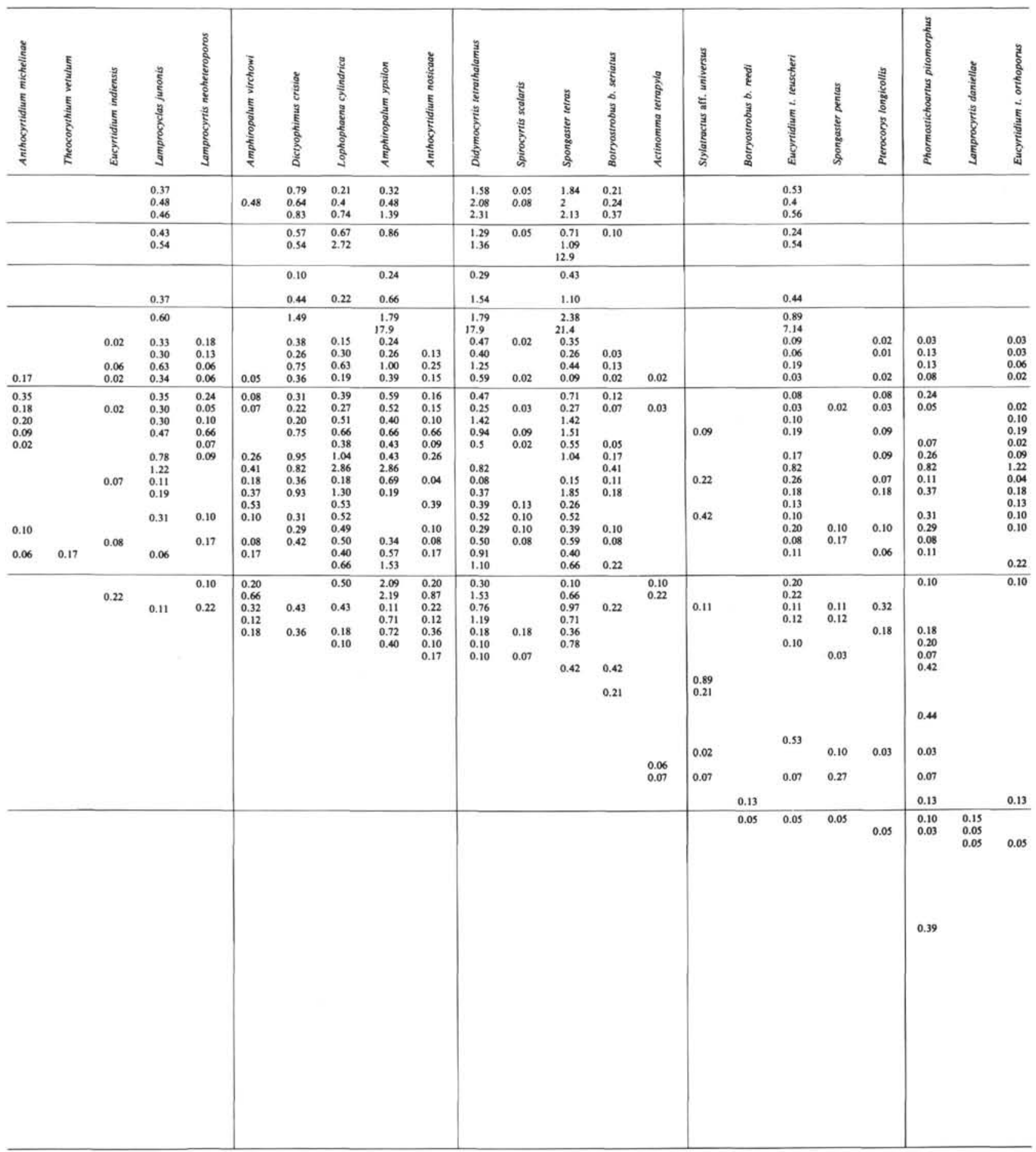

The first occurrence of Lamprocyrtis nigriniae in Sample 586B-1-5, 60-62 cm places this sample in Zone NR4 and the last occurrence of Anthocyrtidium angulare in Sample 586B-4-1, 60-62 cm places this sample in Zone NR5. But the limit between Zones NR4 and NR5 is difficult to position, because radiolarians are rare and dissolved in Sample 586B-3-2, 60-62 cm to 586B-3-6, 60$62 \mathrm{~cm}$. The presence of Pterocanium prismatium in Sample 586B-4-6, 60-62 cm, places Samples 586B-4-1,
$60-62 \mathrm{~cm}$ to $586 \mathrm{~B}-4-5,60-62 \mathrm{~cm}$ in the early Pleistocene Zone NR5. The first occurrence of $A$. angulare in Sample 586B-5-4, 60-62 cm is just below the Pliocene/Pleistocene boundary.

Radiolarians are rare and are moderately to well preserved in the upper Pliocene. Shells are often dissolved and poorly preserved in the middle to late Spongaster pentas Zone. The latest occurrence of Stichocorys peregrina marks the bottom of the Pterocanium prismatium 
Table 1. (Continued).

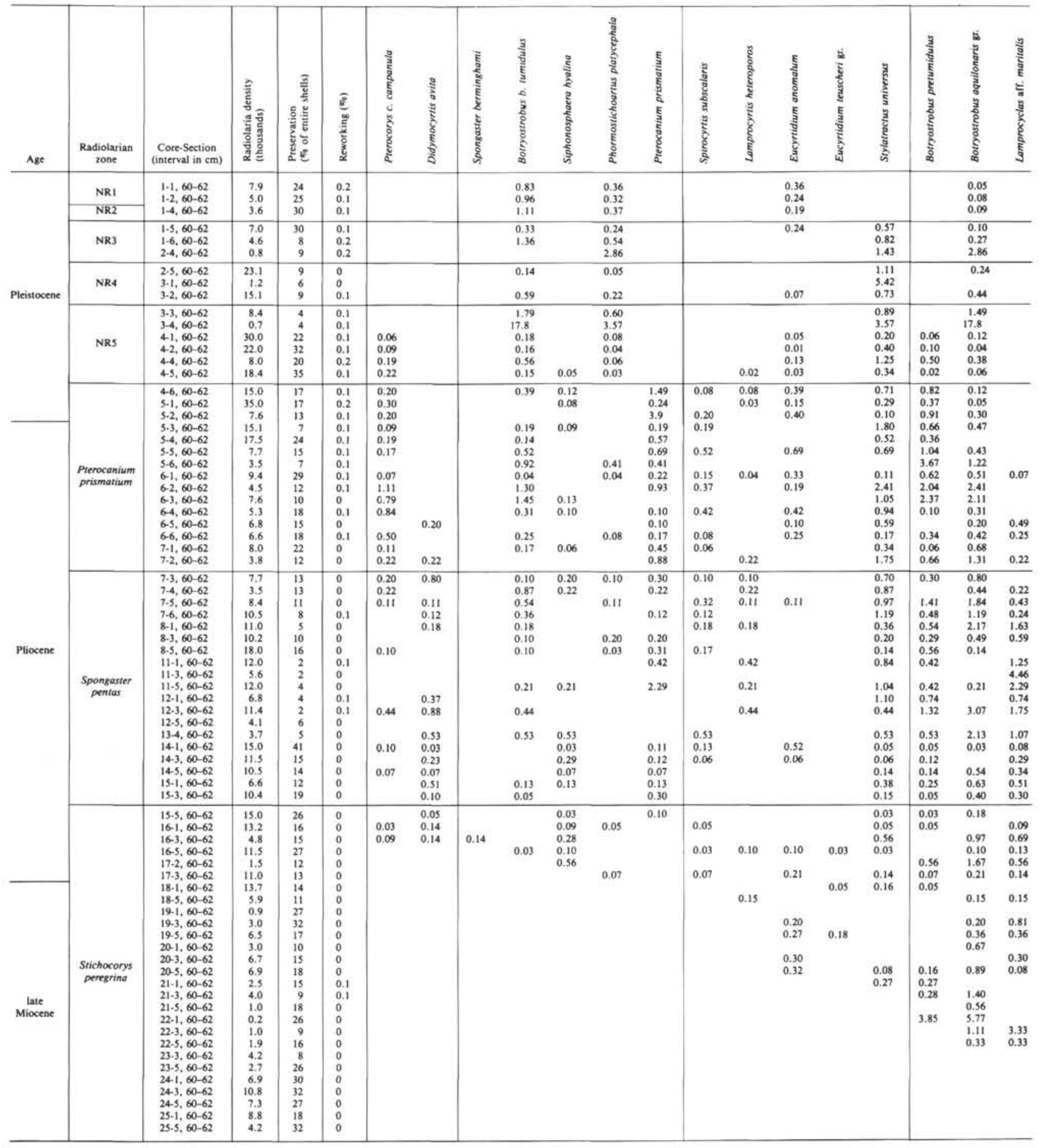

Zone between Samples 586B-7-3, 60-62 cm and 586B-7-2, $60-62 \mathrm{~cm}$. The event indicating the bottom of the Spongaster pentas Zone is the evolutionary transition between Spongaster berminghami and $S$. pentas. Because $S$. berminghami is rare, this event cannot be used in Hole 586B. Thus, the bottom of the $S$. pentas Zone occurs in the interval between Samples 586B-16-3, 60-62 cm (occurrence of $S$. berminghami) and 586B-15-3, 60-62 cm (first occurrence of $S$. pentas). This conclusion is supported by the first occurrence of Didymocyrtis avita in Sample 586B-16-3, 60-62 cm and the morphotypic bottom of Pterocanium prismatium in Sample 586B-15-5, 60-62 cm.

Although few individuals of Stichocorys peregrina and numerous ones of $S$. delmontensis occur in Samples 586B$24-3,60-62 \mathrm{~cm}$ to $586 \mathrm{~B}-25-5,60-62 \mathrm{~cm}$, the evolutionary transition between the two species cannot be reported, and the bottom of the Stichocorys peregrina Zone remains below the last sample cored. Thus, the interval 
Table 1. (Continued).

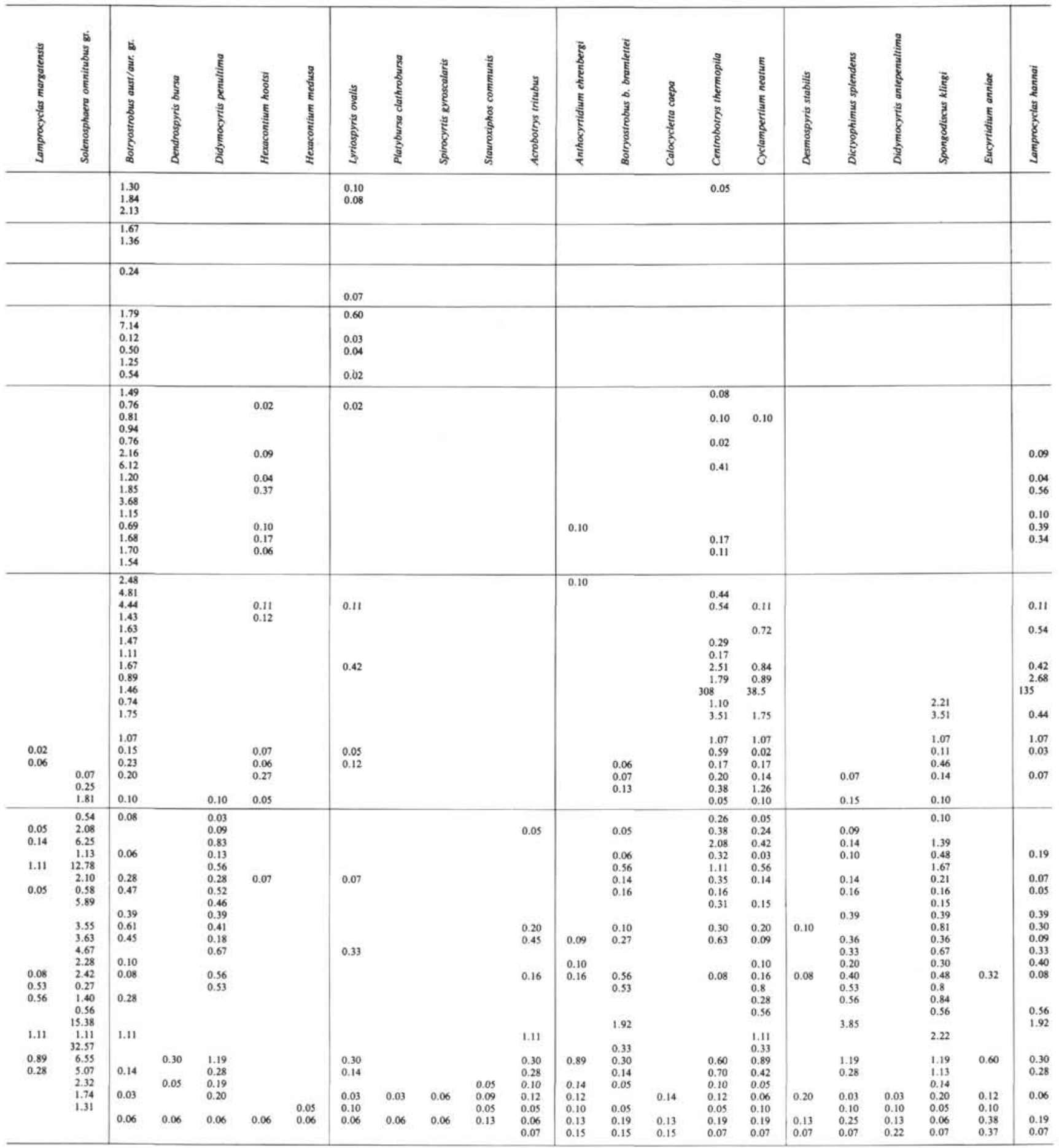

between Samples 586B-15-3, 60-62 cm and 586B-25-5, $60-62 \mathrm{~cm}$ is placed in the late Miocene $S$. peregrina Zone.

\section{Site $\mathbf{5 9 2}$}

At Site 592, radiolarians are present in only part of the upper Eocene. Samples available for radiolarian studies range from Sections 592-37-1 to 592-40-5. Well-preserved radiolarian faunas are present in Sample 592-40$4,40-42 \mathrm{~cm}, 592-40-3,40-42 \mathrm{~cm}, 592-40-2,40-42 \mathrm{~cm}$,
592-40-1, 40-42 cm, 592-39-4, 40-42 cm, and 592-39-3, $40-42 \mathrm{~cm}$. Very rare specimens are present in Samples $592-37-4,15-16 \mathrm{~cm}$ and 592-37-3, 15-16 cm. Samples $592-37-1,15-16 \mathrm{~cm}$ and $592-37-2,15-16 \mathrm{~cm}$ contain only some fragments.

As radiolarian assemblages are different in tropical and polar areas, dating of temperate latitude sediments by the use of either the low-latitude or the high-latitude radiolarian biostratigraphy is often unsuccessful. Fortu- 
Table 1. (Continued).

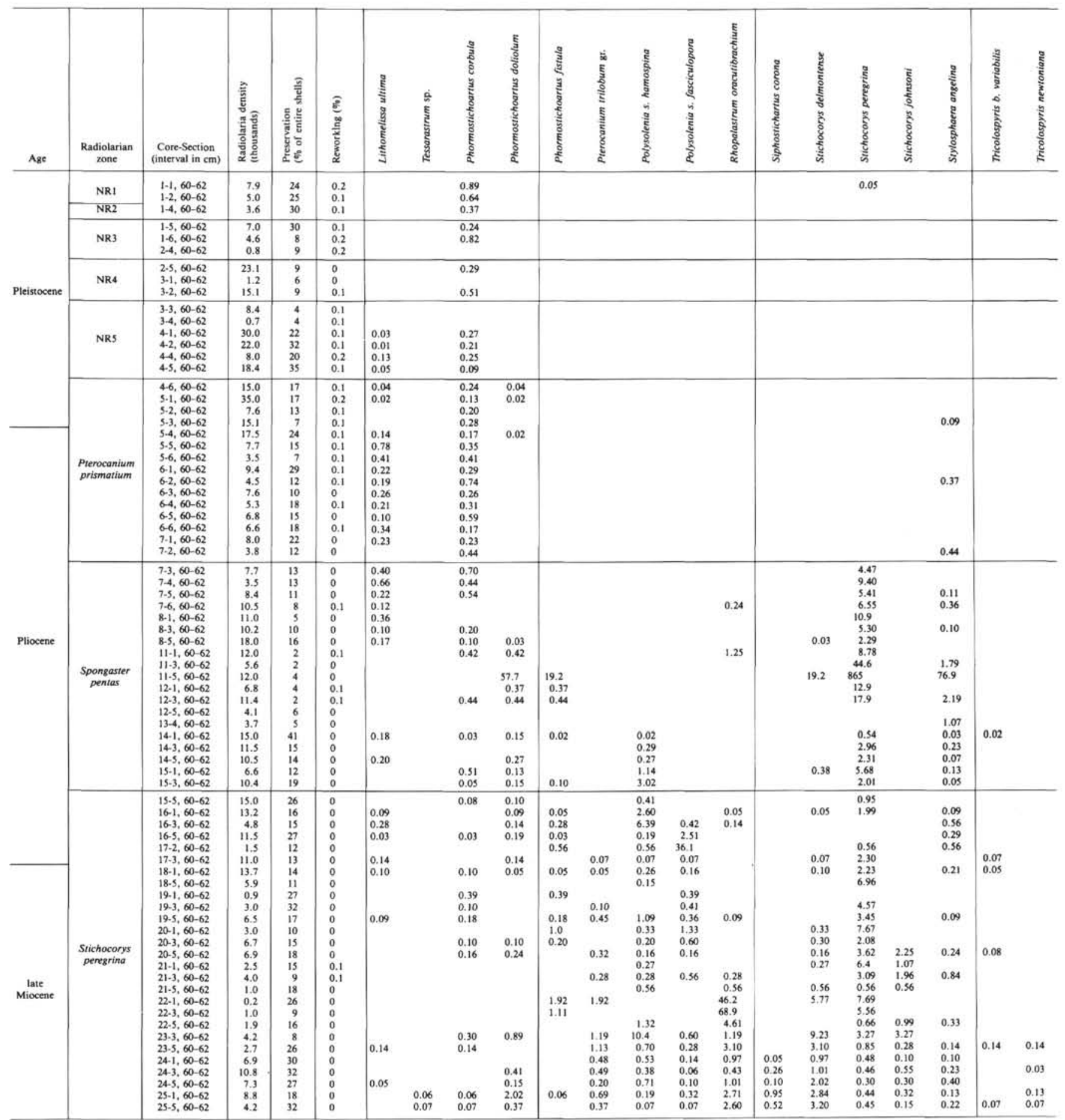

nately, late Eocene radiolarian assemblages from Site 592 are not very different from tropical faunas and thus the classic biostratigraphy of Riedel and Sanfilippo (1978) can be used.

Radiolarian abundances were roughly estimated from the density of radiolarians on strewn slides, from counts of 2000 to 5000 well-preserved tests for each sample. A large number of morphotypes were encountered, but only 39 well-known forms are tabulated in Table 2 . A con- siderable amount of taxonomic work remains to be completed to describe the other morphotypes but because very little material is available, the descriptions and the ranges will be prepared for separate publication with other material cored on the Kerguelen Plateau.

Only one radiolarian zone was identified in Site 592: the Cryptoprora ornata Zone from Sections 592-39-3 to 592-40-4. The C. ornata Zone (= top of the former Thyrsocyrtis bromia Zone of Riedel and Sanfilippo, 
Table 2. Abundance of some radiolarians from Hole 592.

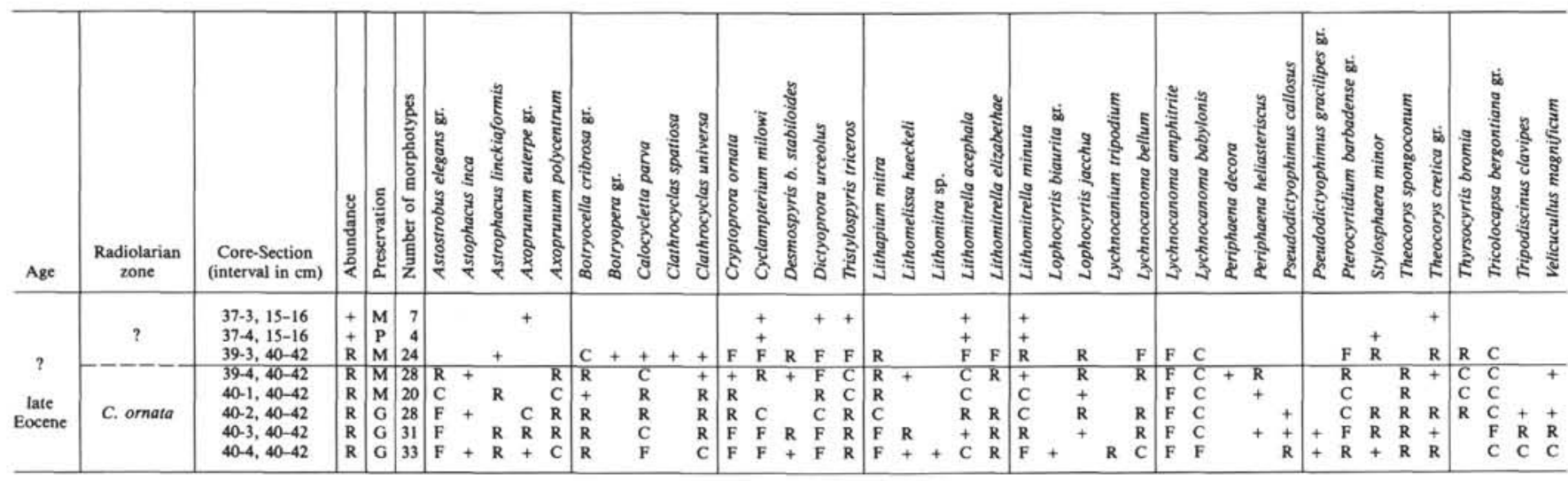

Note: Morphotype abundances: $+=$ one specimen; $R=$ rare (less than 5 specimens); $C=$ common (between 5 and 20 specimens); $F=$ frequent (more than 20 specimens). Abundance of radiolarians in samples: $+=$ very rare; $\mathbf{R}=$ rare. Preservation: $\mathrm{P}=$ poor; $\mathrm{M}=$ moderate; $\mathbf{G}=$ good.

emended by Maurrasse and Glass (1976) and Saunders et al. (in press), is the uppermost radiolarian zone of the Eocene. Since no radiolarian forms were found in sediments of early Oligocene age, the Eocene/Oligocene radiolarian boundary cannot be located at Site 592 .

Late Eocene radiolarian assemblages from Site 592 are similar to tropical faunas but lack some typical morphotypes, like the Lithocyclia group. Other tropical species like Thyrsocyrtis bromia appear to be rare and are restricted to the upper part of the radiolarian zone. However, their skeletons are somewhat different from the tropical forms. The tests of Cyclampterium(?) milowi are frequent, but the test outline is narrower in the mid-latitude assemblages. Some forms like Lychnocanoma amphitrite and Lithapium mitra are more frequent than in the tropical assemblages. As shown by Chen (1975), highlatitude radiolarian assemblages "are similar to but less diverse than the late middle Eocene to late Eocene lowlatitude assemblages previously described by Riedel and Sanfilippo (1971) and Foreman (1973)." Petrushevskaya (1975) reported that Eocene radiolarian faunas from the South Pacific sector of the Southern Ocean (DSDP Leg 29) are more similar to the Californian Eocene assemblages than those from the Caribbean. This is also the case for Eocene radiolarians from Site 592.

The preservation of the tests is good only in Samples 592-40-2, 40-42 cm, 592-40-3, 40-42 cm and 592-40-4, $40-42 \mathrm{~cm}$. In these samples, the diversity of morphotypes is higher and diatoms are more abundant. In Sample 592-39-3, 40-42 cm the siliceous fraction is represented only by broken radiolarian tests. In Samples 592-37-3, $15-16 \mathrm{~cm}$ and $592-37-4,15-16 \mathrm{~cm}$, the number of the forms found is low and their state of preservation poor. It may be concluded that the deposition of radiolarians and other siliceous microfossils ceased at Site 592 before the very end of the late Eocene and that reworking processes are responsible for the rare latest Eocene siliceous accumulations near the Eocene/Oligocene boundary.

\section{Site 594}

Radiolarians are rare throughout the core recovered at Site 594; moderately to well-preserved faunas are encountered in all cores.
Stratigraphic correlation of Neogene Radiolaria from Site 594 is difficult because siliceous material is scarce and greatly diluted by terrigenous material, and paleoenvironments have changed. Because warm-water and polar assemblages are mixed, zonations proposed for both regions have been employed. Samples 594-1-1, 84-86 cm to $594-6-4,84-86 \mathrm{~cm}$ contain a typical late Quaternary (less than 400,000 yr.) antarctic radiolarian assemblage that can be assigned to the Antarctissa denticulata Zone or NR1 Zone. Common species include $A$. denticulata, A. strelkovi, Theocalyptra davisiana, and Rhizosphaera antarctica.

Samples $594-7-2,84-86 \mathrm{~cm}$ to $594-8-1,84-86 \mathrm{~cm}$, below the last appearance of Stylatractus universus in 594$7-2,84-86 \mathrm{~cm}$, are placed in Zone NR2 (Quaternary). The next marker observed was Phormostichoartus pitomorphus $\mathrm{n}$. $\mathrm{sp}$. (described in this chapter) whose last occurrence is in Sample 594-9-4, 84-86 cm. Therefore, Samples $594-9-4,84-86 \mathrm{~cm}$ to $594-11-5,84-86 \mathrm{~cm}$ are in the NR3/NR4 Zone (early to middle Pleistocene). It is not possible to distinguish between NR3 and NR4 because of the lack of warmer-water species.

Clathrocyclas bicornis occurs sporadically between Samples 594-11-6, 84-86 cm and 594-14-2, 84-86 cm. This occurrence is interpreted as reworking, because the first consistent occurrences of $A$. denticulata and Theocalyptra bicornis were found in Sample 594-12-3, 84-86 $\mathrm{cm}$. Thus, Samples 594-11-6, 84-86 cm to 594-14-4, 84$86 \mathrm{~cm}$ are placed in the NR4 Zone.

The last consistent occurrence of C. bicornis in Sample $594-15-2,84-86 \mathrm{~cm}$ is used to mark the top of the Pliocene. Rare radiolarians occur in Samples 594-15-2, $84-86 \mathrm{~cm}$ to $594-20-3,84-86 \mathrm{~cm}$. Typical Pliocene species like Pseudocubus vema occur sporadically. Because preservation was poor and markers were scarce the interval between Samples 594-15-2, 84-86 cm and 594-20-3, $84-86 \mathrm{~cm}$ remains unzoned.

Samples 594-20-4, 84-86 cm to 594-27-1, 84-86 cm, below the first occurrence of Antarctissa ewingi and above the first appearance of Stichocorys peregrina, are placed in the Stichocorys peregrina Zone (late Miocene). In the best preserved samples, forms like Anthocyrtidium ehrenbergi and Hexacontium hootsi indicate warmer condi- 
Table 3. Abundance of some radiolarians from Hole 594.

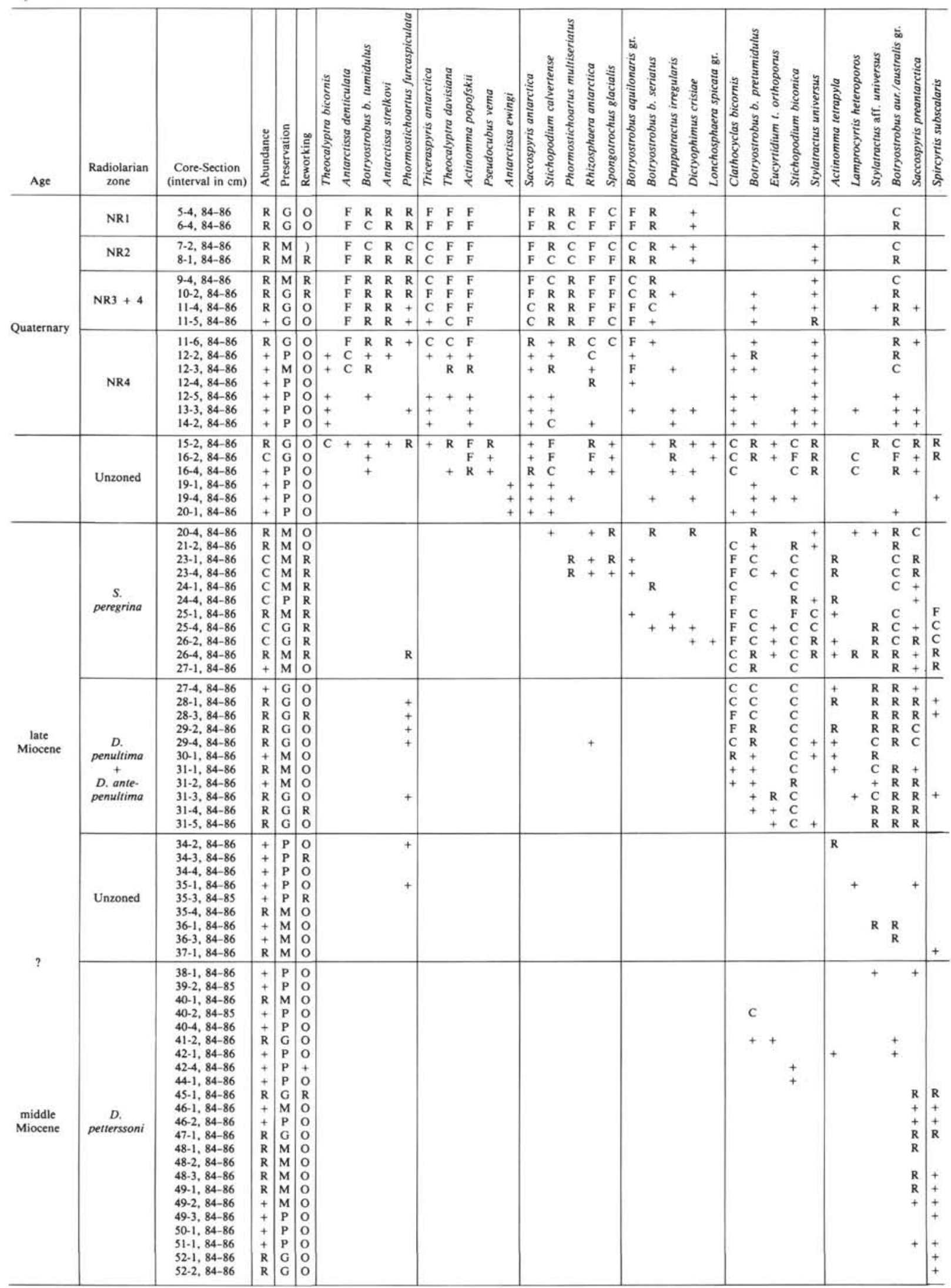

Note: Symbols as for Table 2. The following samples were barren of radiolarians: $594-18-1,84-86 \mathrm{~cm} ; 594-18-2,84-86 \mathrm{~cm} ; 594-18-4,84-86 \mathrm{~cm} ; 594-21-4,84-86 \mathrm{~cm} ; 594-34-1$, $84-86 \mathrm{~cm} ; 594-34-5,84-86 \mathrm{~cm} ; 594-38-2,84-86 \mathrm{~cm} ; 594-41-3,84-86 \mathrm{~cm} ; 594-41-4,84-86 \mathrm{~cm} ; 594-43-1,84-86 \mathrm{~cm}$. 
Table 3. (Continued).

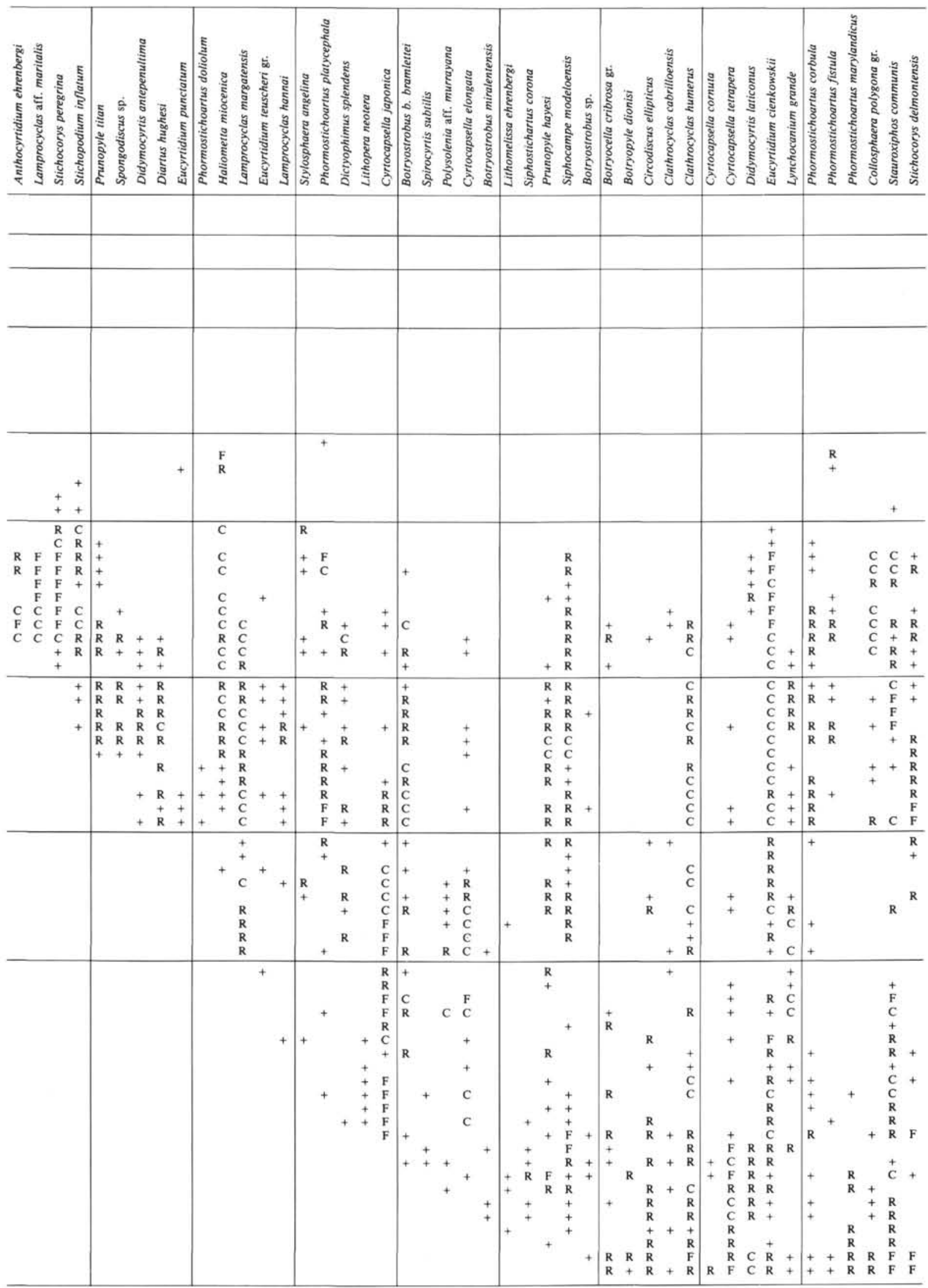


tions. Reworked specimens of Eocene to middle Miocene age occur in Samples 594-23-1, 84-86 cm to 594-26-4, $84-86 \mathrm{~cm}$.

The next markers observed were Didymocyrtis antepenultima and Diartus hughesi, whose first appearances are tabulated in Sample 594-31-5, 84-86 cm. Thus, Samples 594-27-4, 84-86 $\mathrm{cm}$ to $594-31-5,84-86 \mathrm{~cm}$ are placed in the Didymocyrtis antepenultima Zone and the D. penultima Zone. The $D$. penultima and $D$. antepenultima zones are amalgamated because the species $D$. penulti$m a$ was not found in the radiolarian assemblages. Moreover, the base of the $D$. penultima Zone, which is also recognized in tropical areas at the top of the range of Diartus hughesi, cannot be located in Site 594 because the last occurrence of $D$. hughesi is tabulated in the $S$. peregrina Zone. It is possible that $D$. hughesi as well as Didymocyrtis laticonus and $D$. antepenultima have different ranges in the mid-latitude sediments. Close examinations of numerous specimens show distinct morphological differences with tropical forms. Further studies, including size measurements, are needed to estimate the importance of these morphologic differences (Caulet, in preparation).

Samples $594-31-6,84-86 \mathrm{~cm}$ to $594-37-1,84-86 \mathrm{~cm}$ contain poorly preserved and rare radiolarian assemblages. Barren levels occur sporadically throughout this interval, which cannot be related to a well-defined zone.

Most radiolarian species recognized in the samples below 594-37-1, 84-86 cm are well known in the tropical assemblages of the Diartus petterssoni Zone (middle Miocene). The most significant transition in the radiolarian fauna is observed between Cores 594-23 and 594-21. In Core 21 and above, most temperate or warm-water radiolarians have disappeared. Radiolarian abundances are greatly reduced and antarctic or subantarctic species become more dominant. Their occurrence suggests a northward migration of the Antarctic Convergence.

\section{DISCUSSION}

\section{Radiolarian Events and Potential Datum Levels}

Figure 1 summarizes the sequence of events at Hole $586 \mathrm{~B}$ and Site 594 for which adequate stratigraphic coverage is available. The list includes only those events which appear to be of potential stratigraphic significance.

Comparison between the sites shows that not all the available stratigraphically important species are reliable over the equatorial to subantarctic area. Only 14 events from a total of 38 (in the same stratigraphic interval) can be reported from both sites. Most of the correlation lines present no problem, but there are a few conflicts.

1. The discrepancy between the position of the upper limit of Stichocorys delmontensis in Holes 586B and 594 is resolved in favor of Hole 586B by the reliability indices (14 in Hole 586B and 7 in Hole 594). However, the last occurrence of this morphotype is very difficult to place because in temperate latitudes the shells of $S$. peregrina present many variations that are probably due to different local environments (W. R. Riedel, personal communication).

2. There is also a great discrepancy between the relative positions of the upper limit of Phormostichoartus fistula. The stratigraphic range assigned to this species by Nigrini (1977) is large: from the Thyrsocyrtis bromia Zone to the Spongaster pentas Zone. In Hole 586B, the upper limit of this species is located in the $S$. pentas Zone, but in Site 594, its last occurrence is tabulated in the Stichocorys peregrina Zone. However, the indices of reliability ( 20 at Hole 586B and 1 at Hole 594) show that the discrepancy is not due to different paleoenvironmental conditions.

3. The upper limit of Lamprocyclas aff. maritalis is also located in different radiolarian zones: the Pterocanium prismatium Zone at Hole $586 \mathrm{~B}$ and the $S$. peregri$n a$ at Site 594. But the indices of reliability present the same value (25) and the discrepancy seems to be due to paleoecological fluctuations. However, the subantarctic morphotypes could be different from equatorial ones.

In addition to previously reported datum levels, several last occurrences that may be of stratigraphic significance (possibly only local) are worth noting here:

1. Top of Phormostichoartus pitomorphus. The last occurrence of this species is located in the early to middle Pleistocene in Hole 594 and near the Pliocene/Pleistocene boundary in Hole 586B. However, this species is consistently present in the sediments of the subantarctic area but is only scarce and sporadic in equatorial samples of the same age. The indices of reliability are difficult to calculate in the equatorial case and do not allow interpretation of the results. Data from current studies on Indian Ocean cores show this species gradually disappearing in cores located at different latitudes (Caulet, in preparation).

2. Top of Lamprocyrtis heteroporos. This species reaches an upper limit at the Pliocene/Pleistocene boundary in Hole 586B. However, it persists into the Pleistocene at Site 594.

3. As previously noted by Weaver (1983), the last occurrence of Diartus hughesi is higher in subantarctic material (in the Didymocyrtis antepenultima/D. penultima Zone in Hole 594, just below the first evolutionary transition to $S$. peregrina).

\section{Evolutionary Lineages}

Of importance for biostratigraphic application of the information included in this report are several suggested evolutionary transitions. Some of these are new, whereas others are modifications of trends previously reported in other areas.

1. Eucyrtidium teuscheri gr.-E. teuscheri teuscheri (Fig. 2) The E. teuscheri gr. evolves from large eucyrtids, which are rare in the middle Miocene, to slender forms in the late Miocene. These big specimens evolve into E. teuscheri orthoporus and E. teuscheri teuscheri. In the temperate area (Site 594), the transition to E. teuscheri orthoporus occurs in the late Miocene. In the tropical area (Hole 586B), E. teuscheri orthoporus evolves from the E. teuscheri gr. in the beginning of the Spongaster pentas Zone. This species reaches extinction without apparent descendants in the early Pleistocene. Intermediate forms between the E. teuscheri gr. and its two descendants are reported in the late Miocene to early Pliocene. The modern E. teuscheri teuscheri morphotypes evolve in the early $S$. pentas Zone. As $E$. teuscheri 


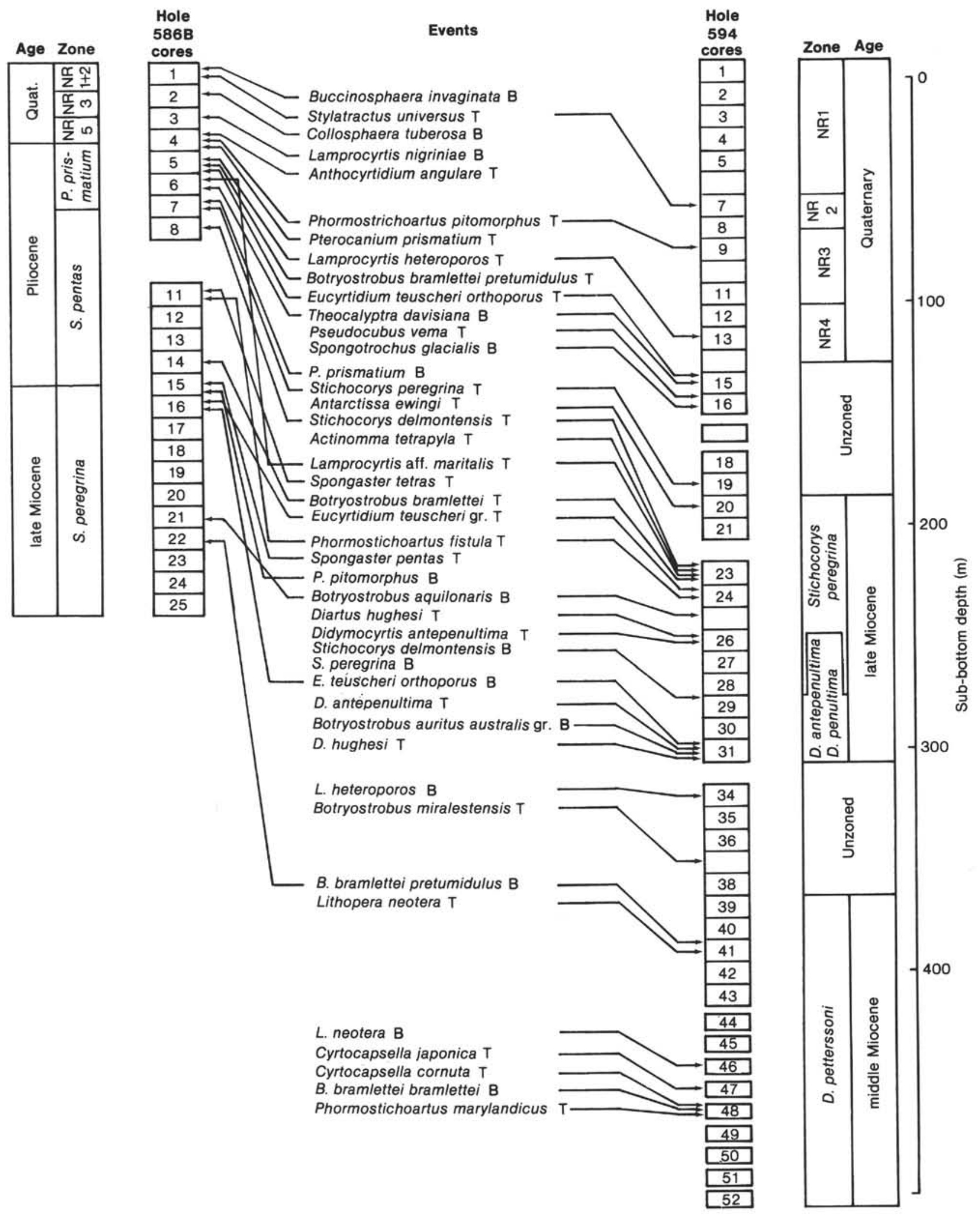

Figure 1. Correlation of radiolarian events in Holes 586B and 594. $\mathrm{B}=$ bottom marker, $\mathrm{T}=$ top marker. 


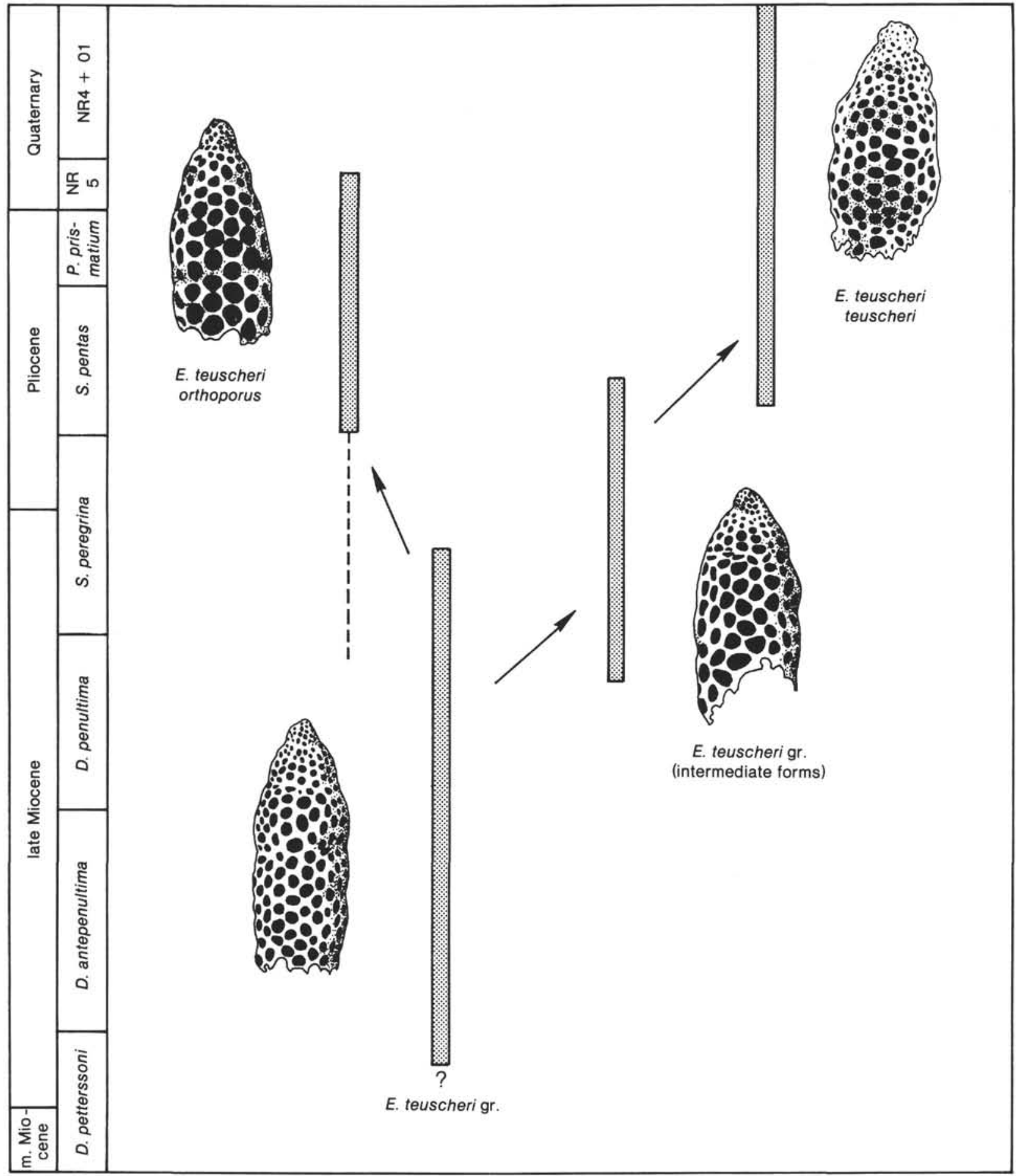

Figure 2. Range chart of relationships among the Eucyrtidium teuscheri group. The broken line indicates the subantarctic range of $E$. teuscheri orthoporus at Site 594.

orthoporus appears to be more frequent in the temperate sediments with a longer range, its evolution is probably controlled by paleoenvironmental conditions.

2. Phormostichoartus fistula-P. pitomorphus (Fig. 3) Phormostichoartus fistula is reported to appear in the late Eocene (Nigrini, 1977). It is rare in late Miocene sediments of both tropical and temperate areas. The transition to $P$. pitomorphus occurs in the early Pliocene.
Transitional forms present gradually shorter tests and the width of the third segment increases. $P$. pitomorphus is more frequent in temperate to subtropical areas (Caulet, unpublished data), and becomes extinct in the early Pleistocene.

Intermediate forms with the $P$. platycephala gr. occur in the late Pliocene period: fourth segment smaller and enlarged cephalis. As $P$. platycephala gr. specimens are 


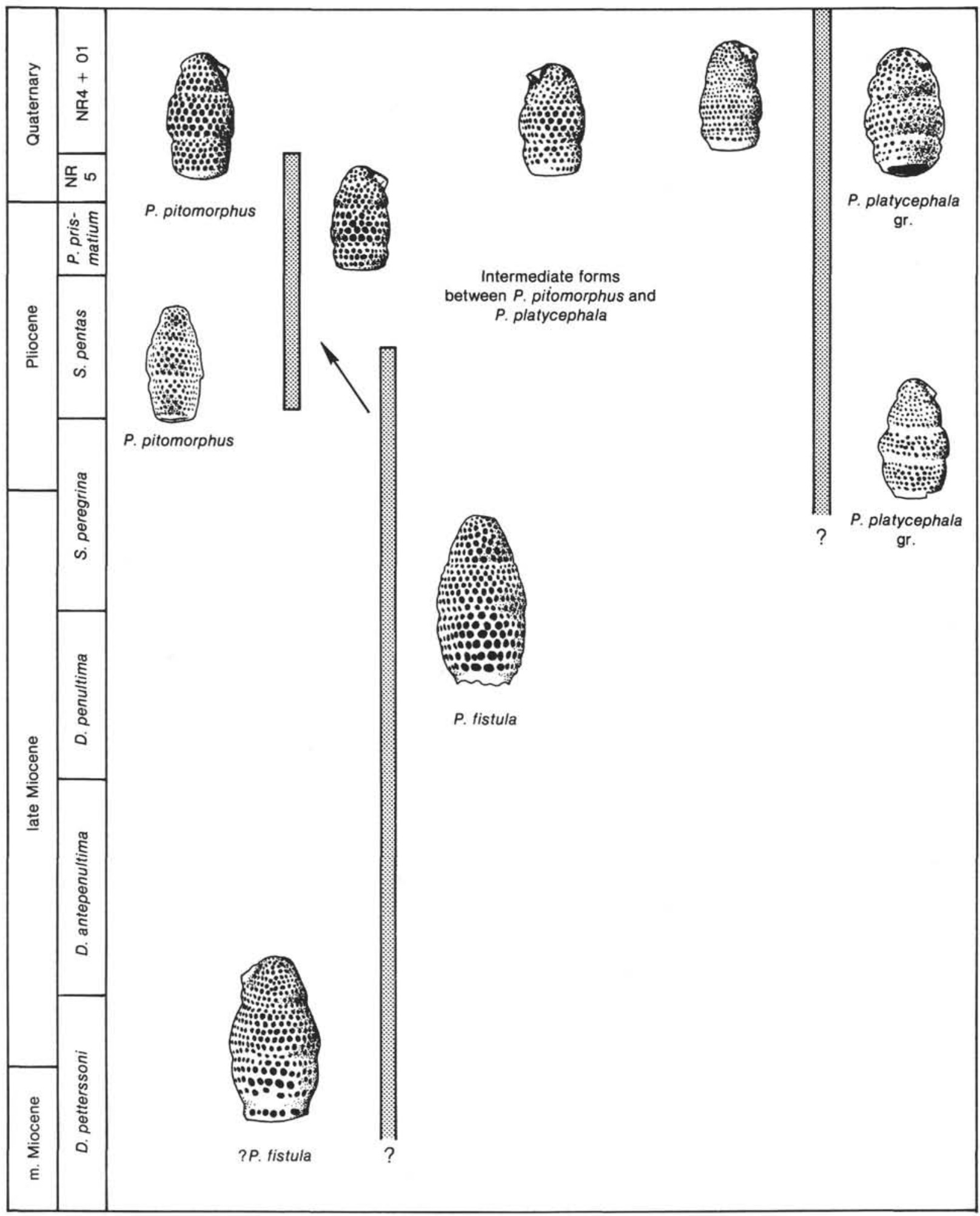

Figure 3. Range chart of relationships among the Phormostichoartus fistula-P. pitomorphus group. $P$. fistula has a widespread distribution in tropical and temperate areas. Its evolution into $P$. pitomorphus took place only in temperate areas. Intermediate forms between $P$. pitomorphus and $P$. platycephala group are commonly found in temperate sediments of Pliocene to early Pleistocene age. Relations between $P$. platycephala and $P$. fistula are not clear. 
present in Messinian sediments (Caulet, unpublished data), it is possible that a hybridization takes place between the two groups of morphotypes. However, older ancestors of $P$. platycephala are unknown, and the phylogeny of the whole groups is not yet precise.

3. Lamprocyclas aff. maritalis-L. maritalis. L. maritalis appears approximately in the early Pterocanium prismatium Zone, where it probably evolves from the $L$. aff. maritalis gr. The relationships with the temperate forms of the same age are not clear.

4. Lamprocyrtis heteroporos-L. nigriniae. The discovery of $L$. daniellae calls into question the lineage proposed by Kling (1973) for the open-cephalis pterocoryds. But the distinction between Lamprocyclas junonis and Lamprocyrtis neoheteroporos and the range of Lamprocyclas hannai remain problematical. Before changing the phylogeny of this group, it is necessary to answer these questions, and to define precisely the stratigraphic range of Lamprocyrtis daniellae, which seems, unfortunately, to be very rare.

\section{Preservation}

Estimates of radiolarian preservation are generally imprecise. Preservation is considered "good" where a large number of species is present, and some skeletons of each species are reasonably complete. Samples in which incomplete specimens are frequent are considered to have "poor" preservation. Samples in which species diversity and specimen integrity are intermediate between the two are included in the "moderate" preservation category. The location of most Leg 90 sites under the mid-latitude water masses and in shallow depths is responsible for the absence or poor preservation of the radiolarian assemblages.

Some aspects of radiolarian preservation in Hole 586B are noteworthy (Fig. 4). Preservation appears to have been very poor during the middle Pleistocene and the middle Pliocene. Very good preservation occurred during the early Pleistocene and the early Pliocene. It is beyond the scope of this report to examine all the possible explanations for these events. However, some radiolarian and diatom contents measured in a few mid-latitude piston cores from the Indian Ocean have been shown to increase in the early Pleistocene and in the early Pliocene (Caulet, 1977). These greater amounts were interpreted as an increase of equatorial productivity. Thus, as biogenous silica dissolution is nearly constant in shallow-water sediments above the CCD (Johnson, 1975), the peaks of the preservation curve at Hole 586B can be interpreted as periods of increasing productivity.

\section{SYSTEMATICS}

The systematic study of radiolarians from Leg 90 is presented in two parts:

1. Taxonomic notes: descriptions of new species with or without revised concepts of the genus

2. Species list: bibliographic references for well-known taxa which are not discussed in the taxonomic notes.

The only literature references given are to the original description, and to my present concept of the species, if different from the original one. Type specimens are deposited in the Muséum National d'Histoire Naturelle, Paris. Measurements have been made on 20 specimens.

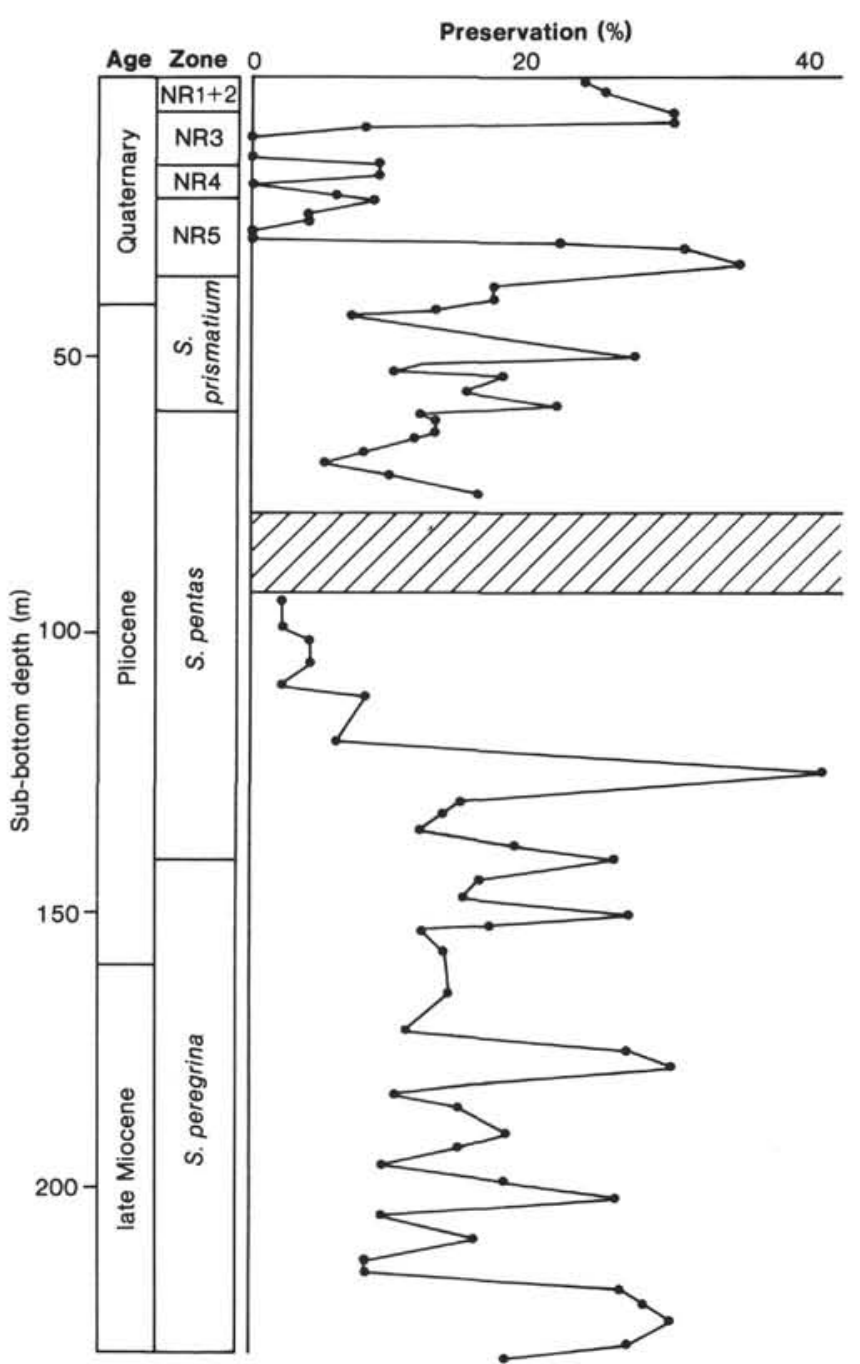

Figure 4. Fluctuations of radiolarian preservation in Hole 586B (in percentages of well-preserved individuals among 800 radiolarian shells). Hatched area shows barren samples.

Taxonomic Notes

\section{Family COLLOSPHAERIDAE Müller, 1858 Genus ACROSPHAERA Haeckel, 1881}

Type species. Collosphaera spinosa Haeckel, 1862, p. 536, pl. 34, figs. 12-13. Bjørklund and Goll (1979) gave a good discussion of the genus. However, their choice of $A$. echinoides Haeckel, 1887 as the type species seems questionable (although technically correct), because they assign to $A$. echinoides the rank of a subspecies of $A$. spinosa, which was originally described by Haeckel in 1862 .

\section{Acrosphaera spinosa hamospina n.ssp.}

(Plate 1, Figs. 2, 3)

Description. A subspecies of Polysolenia spinosa characterized by more than 10 strong spines ending in hooks.

Name. Hamus (Latin: hook) and spina (Latin: spine).

Holotype. Pl. 1, Fig. 2, Sample 586B-23-3, 60-62 cm, slide 2.

Dimensions. Shell diameter, 70-90 $\mu \mathrm{m}$; spine length, $60-80 \mu \mathrm{m}$.

Distribution. The first occurrence is not recognized. But the first consistent occurrence seems to be in the Stichocorys peregrina Zone at Sample 586B-24-5, 60-62 cm.

Remarks. This morphotype is closely related to the Acrosphaera echinoides gr. Haeckel and it could be included in that species. But its stratigraphic range is very short and its last appearance is an event 
with a good index of reliability. Very common in equatorial Indian Ocean material of the same age.

\section{Acrosphaera spinosa fasciculopora n.ssp.}

(Pl. 1, Fig. 1)

?Acrosphaera spinosa echinoides (Haeckel) Bjørklund and Goll, 1979, pl. 1, figs. 10, 11 .

Description. Acrosphaera spinosa with 10-15 spines, strong, long, arising from a cluster of pores that are larger than the irregular small pores of the shell and that form small protuberances on the shell surface.

Name. fasciculum (Latin: cluster)

Holotype. Pl. 1, Fig. 1, Sample 586B-20-3, 60-62 cm, slide 1.

Dimensions. Shell diameter, 80-100 $\mu \mathrm{m}$; Spine length, 30-100 $\mu \mathrm{m}$.

Distribution. First occurrence not recognized. Very abundant in samples near the very end of the Stichocorys peregrina Zone (Sample 586B-16-5, 60-62 cm), a few meters below its last occurrence.

Remarks. This subspecies is closely related to the $A$. echinoides group but its external spines are less numerous, longer, and arise from a very typical cluster of larger pores. Its stratigraphic range is narrower, and the last occurrence seems to be a very good event.

\section{Genus SIPHONOSPHAERA Müller, 1858}

Type species. Collosphaera tubulosa Müller, 1855.

\section{Siphonosphaera hyalina n.sp.}

(Plate 2, Fig. 1)

Description. Subspherical shell with two distal tubes and numerous very small circular pores. Extremity of tubes not latticed, perforated by small pores.

Name. hyalin (Greek: glassy).

Holotype. Pl. 2, Fig. 1, Sample 586B-17-2, 60-62 cm, slide 1 .

Dimensions: Total length, $100-130 \mu \mathrm{m}$.

Distribution. First occurrence in the early Pliocene (Sample 586B$17-2,60-62 \mathrm{~cm}$ ). Last occurrence in the early Pleistocene (Sample $586 \mathrm{~B}-4-5,60-62 \mathrm{~cm}$ ).

Remarks. Bjørklund and Goll (1979) point out the problems that arise from collosphaerid taxonomy. They think that all morphotypes can be assigned to one or two genuses. Until a detailed study of tubebearing collosphaerids is completed, it seems more reasonable to use the old genera.

\section{Family ACTINOMMIDAE Haeckel, 1862, emend. Riedel 1967}

Genus AXOPRUNUM Haeckel, 1887, emend. Koslova, 1972

Type species. A. stauraxonium Haeckel, 1887, pl. 48, fig. 4.

\section{?(Axoprunum) monostylum n.sp.}

(Plate 1, Figs. 9-11)

Description. Axoprunum with one single strong polar spine. Three shells subspherical to cuboid; $20-25$ pores on the equatorial plane. The medullary and cortical shells are joined by rods (about 6 ) disposed in the equatorial plane, and by 2 rods going to the opposite poles of the shell. One rod penetrates the cortical shell and forms a strong spine, three-edged and thorny at its end. The other rod projects as a small thorn. Secondary spines, three-edged, often broken, arise from the bars of the third shell.

Name. monostylus (Latin: with one stylus).

Holotype. PI. 1, Fig. 9, Sample 586B-5-4, 60-61 cm, slide 1 .

Dimensions. Polar spine length: $100-120 \mu \mathrm{m}$. Shell diameter: $80-$ $90 \mu \mathrm{m}$.

Distribution. Very rare in the sediments of the upper Pterocanium prismatium Zone. First common occurrence in Sample 586B-6-1, 60$61 \mathrm{~cm}$. Last occurrence in Sample 586B-4-6, 60-61 cm.

Remarks. Very similar morphotypes can be found in some Langhian marls from Spain (Pl. 1, Fig. 11) (Caulet, unpublished results). But these older forms possess shells with $35-40$ small pores. A nearly dissolved specimen was found in Sample 586B-20-3, 60-61 cm, but it is difficult to describe with precision.

Assignment of a generic name to this morphotype poses a difficult taxonomic problem. Vinassa (1900) describes two Prunoidea and two Sphaeroidea with a single polar spine (Dorydruppa, Doryprunum and Dorysphaera, Dorylonchidium). But the descriptions are very sketchy and the figures of his species cannot be compared to this species. As the inner structure of $A$. monostylum seems to be similar to the inner structure of $A$. stauraxonium, this new morphotype is provisionally ascribed to the genus Axoprunum.

\section{Family SPONGODISCIDAE Haeckel, 1862, emend. Riedel, 1967} Genus RHOPALASTRUM Ehrenberg, 1847

Type species. Haliomma lagena Ehrenberg, 1840, p. 200. See discussion in Nigrini and Moore, 1979, p. 580.

\section{Rhopalastrum oracutibrachium n.sp.}

(Plate 2, Fig. 4)

Description. Spongodiscid with three simple, undivided, spongy arms. Triangular shells, equilateral. Patagium present. Central structure partly obscured by spongy network, consisting of 5 to 6 concentric chambered rings. Spongy arms with sharp edges and ragged ends.

Name. ora (Latin: edge), acutus (Latin: sharp), brachium (Latin: arm).

Holotype. Pl. 2, Fig. 4, Sample 586B-23-5, 60-62 cm, slide 2.

Dimensions. Arm length: $120-130 \mu \mathrm{m}$. Inner disk diameter: 70 $80 \mu \mathrm{m}$.

Distribution. First occurrence not recognized. Abundant from Sample 586B-25-5, 60-62 cm to 586B-22-1, 60-62 cm. Last consistent occurrence in the Stichocorys peregrina Zone (Sample 586B-21-3, 60$62 \mathrm{~cm}$ ). Sporadic occurrences in the Spongaster pentas Zone.

Remarks. Some Pleistocene forms present well-marked arm edges, but these forms are smaller and their arm edges less sharp and thick.

\section{Genus SPONGODISCUS Ehrenberg, 1854}

Type species. S. resurgens Ehrenberg, 1854c, p. 66.

\section{Spongodiscus klingi n.sp. \\ (Plate 2, Figs. 2, 3)}

Circular spongodiscid. Kling, 1971, p. 1086, pl. 1, fig. 8.

?Spongodiscid. Johnson, 1974, pl. 9, fig. 18.

?Spongodiscus communis fragilis Riedel, 1953, p. 809, pl. 84, fig. 6 .

Description. Disc circular, spongy, subdivided into three concentric parts, with a regular margin. Inner disc with 4-5 chambered rows partly obscured by a spongy network. Median part of the disc a net of small irregular pores with 5-7 large meshes. External part of the disc strong and spongy with a delicate margin and fragile short spines, often broken.

Name. In honor of S. Kling, who first reported the species.

Holotype. PI 2, Fig. 3, Sample 586B-18-1, 60-62 cm, slide 1.

Dimensions. Total diameter: $210-220 \mu \mathrm{m}$. Median thin area width: $40 \mu \mathrm{m}$. Maximum dimension of larger elliptical pores: $20 \mu \mathrm{m}$.

Distribution. First occurrence not recognized. Last occurrence at Sample 586B-12-1, 60-62 cm in the $S$. pentas Zone.

Remarks. This species differs from all other spongodiscid species in the broader pores located in the median part of the shell. Frequently, the fragile margin is not observed. The number of inner broad pores is variable. Riedel (1953) described a form with a thin region between a plain margin and a central chambered region, without larger pores. Relationships with other spongodiscids unknown.

Family PTEROCORYTHIDAE Haeckel, 1881, emend. Moore, 1972 Genus LAMPROCYCLAS Haeckel, 1881, emend. Nigrini, 1967

Type species. Lamprocyclas nuptialis Haeckel, 1887, p. 1390, pl. 74, fig. 15.

\section{Lamprocyclas aff. maritalis gr.}

(Plate 4, Figs. 1, 2)

Calocyclas margatensis Campbell and Clark in Riedel, 1953, p. 811, pl. 85 , fig. 8 .

?Lamprocyclas aegles gr. Petrushevskaya, 1975, pl. 16, figs. 2-4, non fig. 1. Weaver, 1983, pl. 4, figs. 4-5.

Description. Shell not entirely campanulate, thick-walled, and with a rough surface. Cephalis subspherical, with small subcircular pores, very thick-walled. Stout three-bladed apical horn, 2 or 3 times cephalis length. Lateral lobes not bulging. Primary and dorsal spines do not continue as ribs in the thoracic wall. Thorax cupola-shaped with subcircular pores, arranged in latitudinal rows and increasing slightly in size toward the third segment. Abdomen ovoid, $12-15$ pores on a half 
equator. Peristome well differentiated, poreless, with two rows of teeth. Terminal teeth better developed than subterminal teeth.

Dimensions. Total length: $200-220 \mu \mathrm{m}$. Maximum width: 100 to $110 \mu \mathrm{m}$

Distribution. In Hole 586B, the first occurrence is at Sample 586B$22-5,60-62 \mathrm{~cm}$ in the Stichocorys peregrina Zone; the first common occurrence is in the same zone. In Hole 594, the first occurrence is in the same zone (Sample 594-26-2, 84-86 cm). But in the equatorial area the last occurrence of this species group is in the Pterocanium prismatium Zone (Sample 586B-6-5, 60-62 cm) and in the subantarctic area it is in the $S$. peregrina Zone (Sample 594-23-1, 84-86 cm).

Remarks. The individuals included in this species group are quite variable. They differ from $L$. maritalis by the shape of the cephalis and abdomen. Some specimens with intermediate morphology can be found in Hole 586B, where the first occurrence of L. maritalis maritalis Nigrini is reported $7 \mathrm{~m}$ below the last occurrence of $L$. aff. maritalis. Thus it can be assumed that $L$. aff. maritalis is the ancestor of $L$. maritalis maritalis. $L$. aff. maritalis gr. differs from $L$. margatensis Campbell and Clark by a longer shell, a more ovoid abdomen, and a strong terminal peristome (Pl. 4, Fig. 3). Moreover, the first occurrence of $L$. margatensis in Hole $586 \mathrm{~B}$ is $10 \mathrm{~m}$ below the first occurrence of $L$. aff. maritalis gr., and the last occurrence of $L$. margatensis, in the early Spongaster pentas Zone, is reported $69 \mathrm{~m}$ below the last occurrence of $L$. aff. maritalis gr. A possible evolutionary lineage would be $L$. margatensis $\rightarrow L$. aff. maritalis $\rightarrow L$. maritalis. However, the mid- and high-latitude specimens of $L$. maritalis gr. have more ovoid shells than equatorial ones, with a spherical cephalis, and have a very different range. Relationships between these morphotypes are not well understood and more precise work, including size measurements, is necessary before a detailed description of this group can be presented (Caulet, in preparation).

\section{Genus LAMPROCYRTIS Kling, 1973}

Type species. Lamprocyclas heteroporos Hays, 1965, p. 179, pl. 3, fig. 1.

\section{Lamprocyrtis daniellae n.sp.}

(Plate 3, Figs. 13-16)

Description. Two-segmented form with very small cephalis, open, with irregularly circular pores and a small apical spine arising gradually from the periphery of the cephalis like a short beak. No accessory spines on the periphery of cephalic top. Collar stricture distinct. Thorax spindle-shaped, thick-walled, smooth with subcircular to irregular pores aligned in longitudinal rows. Thorax constricted distally, terminating in a peristome with an irregular row of strong irregular teeth.

Name. In memory of my wife Daniele.

Holotype. Pl. 3, Fig. 14, Sample 586B-16-1, 60-61 cm, slide 1.

Dimensions. Total length: $120-130 \mu \mathrm{m}$. Maximum width: $70 \mu \mathrm{m}$.

Distribution. Very rare in the sediments of the early Spongaster pentas Zone (Samples 586B-16-1, 60-62 cm to 586B-15-3, 60-62 cm).

Remarks. This morphotype is very similar to L. nigriniae (Caulet), with nearly the same shell. But the general shape and structure of the shell, the presence of a well-developed peristome, and the slightly developed apical spine are different. $L$. daniellae could be the ancestor of $L$. nigriniae and the $L$. heteroporos- $L$. nigriniae lineage may need to be revised. However, it is necessary to find evolutionary morphotypes between $L$. daniellae and $L$. nigriniae. As $L$. heteroporos is generally abundant in high-latitude sediments and $L$. nigriniae is restricted to the equatorial area, evolutionary morphotypes like $L$. daniellae must be found in mid-latitude sediments.

\section{Genus PTEROCORYS Haeckel, 1881}

Type species. P. campanula Haeckel, 1887, p. 1316, pl. 71, fig. 3.

\section{Pterocorys longicollis n.sp.}

(Plate 4, Figs. 4, 5)

Description. Shell rather thin-walled. Three-lobed cephalis subdivided into two parts: (1) upper portion, open, cylindrical, with circular pores, bearing a stout three-bladed apical horn, strong, with a great pore at its base; (2) lower "neck," formed by a very prominent dorsal lobe. Primary lateral and dorsal spines continue as ribs in the thoracic wall for about half its length. Sometimes, they are external, forming very small wings. Thorax is large, cupola-shaped with hexagonally framed, circular pores, quincuncially arranged and aligned longitudinally, $12-15$ on a half-equator, $8-10$ in a vertical series. Pronounced lumbar stricture. Abdomen campanulate. Distal end ragged; aperture never observed.

Name. longus (Latin: long), collum (Latin: neck).

Holotype. Pl. 4, fig. 4, Sample 586B-6-2, 60-61 cm, slide 2. (All specimens in Leg 90 samples are broken.)

Dimensions. Apical horn length: $50-60 \mu \mathrm{m}$. Total length of thorax: 40-50 $\mu \mathrm{m}$. Maximum width: $80 \mu \mathrm{m}$.

Distribution. Very rare, with sporadic occurrences in Pliocene samples of Hole 586B. First occurrence in Sample 586B-15-5, 60-62 cm. Last occurrence in early Pleistocene, Sample 586B-4-1, 60-62 cm. More abundant in high-latitude sediments of Pliocene to early Pleistocene age from the Indian Ocean.

Remarks. Distinguished from the $P$. campanula group by pronounced bulging of the "D-lobe." Also more elongated, with abdomen walls not curved.

Family ARTOSTROBIIDAE Riedel, 1967, emend Foreman, 1973 Genus PHORMOSTICHOARTUS Campbell, 1951, emend. Nigrini, 1977

Type species. Cyrtophormis cylindrica Haeckel, 1887, p. 1461, pl. 77, fig. 17.

\section{Phormostichoartus pitomorphus n.sp.}

(Plate 3, Figs. 3, 4, 9, 10, 12)

Description. Shell smooth, spindle-shaped, consisting of four segments. Cephalis conical with well-developed, poreless, vertical tube lying along the thorax for about a third of its total length. Numerous circular pores, hexagonally framed, in regular horizontal rows. No apical horn.

Name. pito (Greek: barrel), morphos (Greek: shape).

Holotype. (Pl. 3, Fig. 12) Sample MD 75072-VI-100 cm.

Dimensions. Total length: $75-80 \mu \mathrm{m}$. Maximum width: $25-30 \mu \mathrm{m}$.

Distribution. Range is detailed in Figure 3. First common occurrence in early Pliocene at Sample 586B-16-1, 60-62 cm. Last occurrence in early Pleistocene (Sample 586B-4-1, 60-62 cm). The disappearance of this morphotype was previously documented in pistoncore sediments from the southern Indian Ocean (Caulet, 1982).

Remarks. Relationships of this species with $P$. fistula and $P$. platycephala are described earlier in this chapter. In specimens of $P$. pitomorphus, the thorax is always longer then the abdomen.

Family THEOPERIDAE Heckel, 1881, emend. Riedel, 1967

Genus EUCYRTIDIUM Ehrenberg, 1847, emend. Nigrini, 1967

Type species. Lithocampe acuminata Ehrenberg, 1844b, p. 84.

\section{Eucyrtidium anniae n.sp.}

$$
\text { (Plate 5. Fig. 10) }
$$

Description. Five- to six-segmented shell, subcylindrical. Very small apical horn, often broken. Thorax longer than other segments. Longitudinal rows of circular pores on second and third segments. Horizontal rows on subsequent segments. Apertural margin rarely observed.

Name. After Annie Maurs who greatly helped in typing the tables.

Holotype. (Pl. 5, fig. 10) Sample 594-31-4, 84-86 cm.

Dimensions. Total length: $90-100 \mu \mathrm{m}$. Thoracic length: $40 \mu \mathrm{m}$. Thoracic width: $50 \mu \mathrm{m}$.

Distribution. First occurrence not recognized. Last common occurrence at Sample 586B-24-3, 60-62 cm (Stichocorys peregrina Zone). Last sporadic occurrence at Sample 586B-20-5, 60-62 cm, (S. peregrina Zone, late Miocene).

Remarks. This morphotype displays numerous resemblances to $E$. punctatum (broad second segment, shape of the shell). It differs by the longitudinal rows on the third segment and a less cylindrical shell. $E$. anniae could be the ancestor of $E$. anomalum, as the first occurrence of this species is recognized at Sample 586B-20-5, 60-62 cm. Close relationship seem to exist between $E$. punctatum, $E$. anniae, and $E$. anomalum, but the oldest species are very rare, occurring sporadically, and further examination is needed.

\section{Eucyrtidium teuscheri gr. (Haeckel) sensu emend.} (Plate 5, Figs. 1-8)

Eucyrtidium teuscheri Haeckel, 1887, p. 1491, pl. 77, fig. 5. Stichopilium variabilis Popofsky, 1908, p. 290, pl. 35, figs. 4-7. 
Description. Four- to six-segmented shell; sinuous sutures between the segments. Cephalis hemispherical with a small, conical horn of the same length. Third segment longer and broader than the others. Fourth joint cylindrical. Apertural margin rarely observed. Cephalis and thorax with small subspherical pores and spiny walls. Vertical and dorsal spines prolonged as slight ribs along the thorax and the upper part of the abdomen. Pores large, subcircular, of variable sizes, and set in irregular, vertical rows.

Distribution. First occurrence not recognized. Rare in the Diartus petterssoni Zone in Hole 594 and in late Miocene to early Pliocene material. Common in late Pliocene to Pleistocene sediments from the subantarctic area, sparse in equatorial sediments of the same age.

Remarks. The individuals included in this group are quite variable. A provisional attempt is made to divide them into different subspecies when first and last occurrences of morphotypes are known. A subspecific name is not assigned to the oldest morphotypes because their first occurrence is unknown and individuals are too rare in the present material for an adequate description. An evolutionary lineage is proposed for late Miocene to living forms of this group (Fig. 2).

\section{Eucyrtidium teuscheri s.sp.indet.}

(Plate 5, Figs. 1-3)

Description. More than 10 vertical rows of pores on the third segment. Fifth segment very short but always recognized. Lateral and dorsal ribs not present on thorax.

Distribution. Rare and sporadic occurrences in the sediments of the Diartus petterssoni to Stichocorys peregrina Zone from Holes 586B and 594. Rare in Messinian samples from Spain and upper Miocene red clays from the South Indian Basin. Last occurrence in the $S$. peregrina Zone at Sample 586B-24-1, 60-62 cm and 594-24-4, 84-86 cm.

Remarks. The individuals included in this species group are quite variable. Further work is necessary to subdivide the group and understand its relationships with other eucyrtids of the same age.

\section{Eucyrtidium teuscheri teuscheri n.ssp.}

(Plate 5, Figs. 5-8)

Eucyrtidium teuscheri Haeckel, 1887, p. 1491, pl. 77, fig. 5 .

Eucyrtidium (?) teuscheri Haeckel in Petrushevskaya, 1967, p. 121, pl. 68 , fig. 1,2 .

Description. Four-segmented form with 8-10 vertical rows of pores on the third segment. External ribs very pronounced. Shell cylindrical after the third segment.

Holotype. Pl. 5, Fig. 6, Sample MD 75071-V-100 cm, slide 1.

Dimensions. Total length: 100-120 $\mu \mathrm{m}$. Thoracic length: $20 \mu \mathrm{m}$. Maximum width: $40 \mu \mathrm{m}$.

Distribution. Very rare in the Spongaster pentas Zone. First common occurrence at Sample 586B-6-1, 60-61 cm in the Pterocanium prismatium Zone. Common in Pleistocene samples.

Remarks. Pleistocene forms are characterized by less cylindrical shells with more irregular pores.

\section{Eucyrtidium teuscheri orthoporus n.ssp.}

$$
\text { (Plate 5, Fig. 4) }
$$

Description. No internal ring between third and fourth segment, but slight stricture externally. Five to six vertical rows of subcircular pores. Shell cylindrical after the second segment.

Name. orthos (Greek: straight), poros (Greek: pore).

Holotype. Pl. 5, Fig. 4, Sample MD 73028-II-30 cm, slide 1 (Crozet Basin, Indian Ocean),

Dimensions. Nearly the same as for E. teuscheri teuscheri.

Distribution. Very rare in tropical sediments. Common in mid-latitude material from the subantarctic area. First occurrence at Sample 586B-16-1, 60-62 cm in the early Spongaster pentas Zone and at Sample 594-31-5, 84-86 cm (Didymocyrtis antepenultima/penultima Zone). Nonsporadic occurrences only in the Pterocanium prismatium Zone. Last occurrence at Sample 586B-4-1, 60-62 cm (early Pleistocene) and at Sample 594-15-1, 84-86 cm (late Pliocene to early Pleistocene). In both Hole 586B and Site 594, the last occurrence of this subspecies has no real significance because radiolarians are absent or very rare in all samples. Previous studies of Indian Ocean piston cores show that the last occurrence of $E$. teuscheri orthoporus occurs in the mid-Pleistocene period between 0.9 and 0.7 m.y. (Caulet, 1982).

\section{Genus STICHOCORYS Haeckel, 1881}

Type species. S. wolffii Haeckel, 1887, p. 1479, pl. 80, fig. 10.

\section{Stichocorys johnsoni n.sp.}

(Plate 6, Figs. 5, 6)

?Theoperid, gen. et sp. indet., Johnson, 1974, pl. 8, fig. 18.

Description. shell with four (or more ?) segments, distinctly separated by constrictions, the first three segments together forming a conical section. Cephalis subspherical, rough, poreless, and bearing a slightly curved apical horn generally longer than the first segment. Thorax subspherical, well developed, having 20-30 irregularly arranged subcircular pores. Third segment conical, longer and broader than any other, bearing two kinds of pores: ordinary small pores on the whole surface and a single row of pores twice as large as the others just below the lumbar stricture. Fourth segment generally ragged with smaller pores irregularly arranged. Entire apertural margin never observed.

Name. After D. A. Johnson, who first reported the morphotype.

Holotype. Pl. 6, Fig. 5, Sample 586B-20-5, 60-62 cm, slide 1 .

Dimensions. Length of first, second, and third segments: 120 $130 \mu \mathrm{m}$. Thoracic length: $40 \mu \mathrm{m}$. Abdominal length: 50-60 $\mu \mathrm{m}$.

Distribution. First occurrence not recognized. Last occurrence in the Stichocorys peregrina Zone (Sample 586B-20-5, 60-62 cm) with a good reliability index.

Remarks. This morphotype seems to be related to the genus Stichocorys by the shape of the shell and the structure of the cephalis. It differs from other stichocorids in having a larger thorax and a big third segment (see figures of $S$. peregrina and $S$. johnsoni with same enlargement, Pl. 6, Figs. 4-6). Johnson and/or Nigrini (personal communication) show that Pacific Ocean forms (PI. 6, Fig. 5) have no indentation on third segment like Indian Ocean forms (Pl. 6, Fig. 6). The species Eucyrtidium diaphanes (= Calocyclas coronata Carneval) is characterized by a single row of large pores just below the lumbar stricture but the shell has a different shape and the stratigraphic range is quite different. $E$. diaphanes could be a probable ancestor of $S$. johnsoni but the relationships between the two morphotypes must be studied more precisely.

\section{Species Lis}

Acanthodesmia circumflexa (Goll). Giraffospyris circumflexa Goll, 1969 , p. 332, pl. 60, figs. 1-4, text-fig. 2. Acanthodesmia circumflexa (Goll) in Petrushevskaya, 1971, p. 274, pl. 142, figs. 4, 5.

Actinomma popofskii n. comb. Echinomma popofskii Petrushevskaya, 1967, p. 23, fig. 12 I-III.

Actinomma tetrapyla (Hays). Prunopyle tetrapyla Hays, 1965, p. 172, pl. 2, fig. 5. Actinomma tetrapyla (Hays) in Petrushevskaya, 1975, p. 569 .

Acrobotrys tritubus Riedel, 1957, p. 80, pl. 1, fig. 5.

Amphirhopalum virchowii (Haeckel). Euchitonia virchowii Haeckel, 1862 , p. 503, pl. 30, figs. 1-4. Amphirhopalum virchowii (Haeckel) in Dumitrică, 1973, p. 835, pl. 9, figs. 2-4; pl. 11, fig. 6; pl. 21, figs. 2-13.

Amphirhopalum ypsilon Haeckel, 1887, p. 522; Nigrini, 1971, p. 447, pl. 34.1 , figs. $7 \mathrm{a}-\mathrm{c}$.

Androspyris anthropiscus Haeckel, 1887, p. 1093, pl. 83, fig. 8.

Antarctissa denticulata (Ehrenberg). Lithobotrys ? denticulata Ehrenberg, 1884a, p. 203. Antarctissa denticulata (Ehrenberg) in Petrushevskaya, 1967 , p. 87 , fig. 49 , I-IV.

Antarctissa ewingi Chen, 1975, p. 457, pl. 16, figs. 5-9.

Antarctissa strelkovi Petrushevskaya, 1967, p. 89, fig. 51, III-VI.

Anthocyrtidium angulare Nigrini, 1971, p. 445, pl. 34.1, figs. 3a-b.

Anthocyrtidium ehrenbergi (Stöhr) gr. Anthocyrtis ehrenbergi Stöhr, 1880 , p. 100 , pl. 3, figs. 21a, b. Anthocyrtidium ehrenbergi (Stöhr) in Riedel et al., 1974, p. 712, pl. 60, fig. 10; pl. 61, fig. 1.

Anthocyrtidium michelinae Caulet, 1979, p. 132, pl. 2, figs. 8, 9.

Anthocyrtidium nosicaae Caulet, 1979, p. 132, pl. 2, fig. 6 .

Artostrobus elegans (Ehrenberg) gr. n. comb. Eucyrtidium elegans Ehrenberg, 1854c, pl. 36, fig. 17; 1875, pl. 11, fig. 12.

Astrophacus inca (Clark and Campbell) n. comb. Heliodiscus inca Clark and Campbell, 1942, p. 38, pl. 3, fig. 17.

Astrophacus linckiaphormis (Clark and Campbell) n. comb. Heliodis cus linckiaphormis Clark and Campbell, 1942, p. 40, pl. 5, figs. 1,2 . 
Axoprunum euterpe (Haeckel) gr. n. comb. Stylosphaera euterpe Haeckel, 1887, p. 135.

Axoprunum polycentrum (Campbell and Clark). Druppatractus (Druppatractus) polycentrus Campbell and Clark, 1942, p. 35, pl. 5, fig. 19. Axoprunum polycentrum (Campbell and Clark) in Petrushevskaya and Koslova, 1972, p. 521, pl. 10, figs. 11-12.

Botryocella cribrosa (Ehrenberg) gr. ? Lithobotrys cribrosa Ehrenberg, 1873 , p. $237 ; 1875$, pl. 3, fig. 20. Botryocella aff. B. cribrosa (Ehrenberg) gr. in Petrushevskaya and Koslova, 1972, p. 554, pl. 39, figs. 4-6.

Botryopyle (?) dionisi Petrushevskaya, 1975, p. 589, pl. 13, fig. 18, pl. 26, fig. 10 .

Botryostrobus aquilonaris (Bailey) gr. Eucyrtidium aquilonaris Bailey, 1856, p. 4, pl. 1, fig. 9. Botryostrobus aquilonaris (Bailey) in $\mathrm{Ni}-$ grini, 1977, p. 246, pl. 1, fig. 1.

Botryostrobus auritus/australis (Ehrenberg) gr. Lithocampe australe Ehrenberg, 1844a, p. 187; 1854b, pl. 35A, 21, fig. 18. Botryostrobus auritus/australis (Ehrenberg) gr. in Nigrini, 1977, p. 246, pl. 1, figs. 2-5.

Botryostrobus bramlettei bramlettei (Campbell and Clark) Lithomitra bramlettei Campbell and Clark, 1944, p. 53, pl. 7, figs. 10-14. Botryostrobus b. bramlettei (Campbell and Clark) in Caulet, 1979, p. 129 , pl. 1, fig. 8.

Botryostrobus bramlettei pretumidulus Caulet, 1979, p. 129, pl. 1, fig. 5.

Botryostrobus bramlettei reedi (Campbell and Clark) n. comb. Siphocampe (Siphocampula) reedi Campbell and Clark, 1944, p. 58, pl. 7 , fig. 24.

Botryostrobus bramlettei seriatus (Jørgensen) Eucyrtidium seriatum Jørgensen, 1905, p. 150. Botryostrobus bramlettei seriatus (Jørgensen) in Caulet, 1979, p. 130, pl. 1, fig. 6, text-fig. 4.

Botryostrobus bramlettei tumidulus (Bailey) Eucyrtidium tumidulus Bailey, 1856, p. 5, pl. 1, fig. 11. Botryostrobus bramlettei tumidulus (Bailey) in Caulet, 1979, p. 131, pl. 1, fig. 9.

Botryostrobus miralestensis (Campbell and Clark) Dictyocephalus miralestensis Campbell and Clark, 1944, p. 45, pl. 6, figs. 12-14. Botryostrobus miralestensis (Campbell and Clark) in Petrushevskaya and Koslova, 1972 , p. 539 , pl. 24, fig. 31.

Buccinosphaera invaginata Haeckel, 1887, p. 99, pl. 5, fig. 11.

Calocycletta caepa Moore, 1972, p. 149, pl. 2, figs. 4-7.

Calocycletta parva Moore, 1972, p. 148, pl. 1, figs. 1-5.

Centrobotrys thermophila Petrushevskaya, 1965, p. 115.

Circodiscus ellipticus (Stöhr) Trematodiscus ellipticus Stöhr, 1880, p. 108, pl. 4, fig. 16. Circodiscus ellipticus (Stöhr) gr. in Petrushevskaya, 1975, p. 575, pl. 6, figs. 1-6.

Clathrocyclas bicornis Hays, 1965, p. 179, pl. 3, fig. 3.

Clathrocyclas (Clathrocycloma) cabrilloensis Campbell and Clark, 1944, p. 48 , figs. 1-3.

Clathrocyclas humerus Petrushevskaya, 1975 , p. 586 , pl. 15 , figs. 7 , $12,22,23$, pl. 43 , figs. $1,2$.

Clathrocyclas spatiosa (Ehrenberg) n. comb. Cycladophora spatiosa Ehrenberg, 1875, pl. 18, figs. 5, 6.

Clathrocyclas (Clathrocyclia) universa Clark and Campbell gr., 1942, p. 87-88, pl. 7, figs. 11-20.

Collosphaera polygona Haeckel gr., 1887, p. 96, pl. 13, fig. 15.

Collosphaera tuberosa Haeckel, 1887, p. 97; Nigrini, 1971, p. 445, pl. 34.1, fig. 1.

Collosphaera sp. A Knoll and Johnson, 1975, p. 63, pl. 1, figs. 1, 2, 7, pl. 2, figs. 4-6.

Cryptoprora ornata Ehrenberg, 1873, p. 222; 1875, pl. 5, fig. 8.

Cyclampterium (?) milowi Riedel and Sanfilippo, 1971, p. 1593, pl. 38 , fig. 3 ; pl. 7 , figs. 8,9 .

Cyclampterium? neatum Sanfilippo and Riedel, 1970, p. 457, pl. 2, figs. 17,18 .

Cyrtocapsella cornuta Haeckel. Cyrtocapsa (Cyrtocapsella) cornuta Haeckel, 1887, p. 1513, pl. 78, fig. 9. Cyrtocapsella cornuta Haeckel in Sanfilippo and Riedel, 1970, p. 453, pl. 1, figs. 19-20.

Cyrtocapsella elongata (Nakaseko). Theocapsa elongata Nakaseko, 1963 , p. 185, pl. 3, figs. 4-5. Cyrtocapsella elongata (Nakaseko) in Sanfilippo and Riedel, 1970, p. 452, pl. 1, figs. 11-12.

Cyrtocapsella japonica (Nakaseko). Eusyringium japonicum Nakaseko, 1963, p. 193, text-figs. 20-21, pl. 4, figs. 1-3. Cyrtocapsella japonica (Nakaseko) in Sanfilippo and Riedel, 1970, p. 452, pl. 1, figs. 13-15.
Cyrtocapsella tetrapera (Haeckel). Cyrtocapsa (Cyrtocapsella) tetrapera Haeckel, 1887, p. 1512, pl. 75, fig. 12. Cyrtocapsella tetrapera (Haeckel) in Sanfilippo and Riedel, 1970, p. 453, pl. 1, figs. 16-18.

Dendrospyris bursa Sanfilippo and Riedel, in Sanfilippo et al., 1973, p. 217, pl. 2, figs. 9-13.

Desmospyris biceps stabiloides (Petrushevskaya). Desmospyris stabiloides Petrushevskaya, 1972, fig. 1, no. 14. Desmospyris biceps stabiloides (Petrushevskaya) in Caulet, 1979, p. 136, pl. 4, fig. 8.

Desmospyris stabilis (Goll) n. comb. Dendrospyris stabilis Goll, 1968, p. 1422 , pl. 173 , figs. $16-18,20$, text-fig. 8 .

Diartus hughesi (Campbell and Clark). Ommatocampe hughesi Campbell and Clark, 1944, p. 23, pl. 3, fig. 12. Diartus hughesi (Campbell and Clark) in Sanfilippo and Riedel, 1980, p. 1010, text-fig. $1, \mathrm{i}$.

Diartus petterssoni (Riedel and Sanfilippo). Cannartus (?) petterssoni Riedel and Sanfilippo, 1970, p. 520, pl. 14, fig. 3. Diartus petterssoni (Riedel and Sanfilippo) in Sanfilippo and Riedel, 1980, p. 1010 , text-fig. $1, \mathrm{~h}$.

Dictyophimus crisiae Ehrenberg, 1854a, p. 241.

Dictyophimus splendens (Campbell and Clark) n. comb. Pterocorys (Pterocyrtidium) splendens Campbell and Clark, 1944, p. 46, pl. 6 , figs. $19,20$.

Dictyoprora mongolfieri (Ehrenberg). Eucyrtidium mongolfieri Ehrenberg, $1854 \mathrm{c}$, pl. 36, fig. 18, B lower. Dictyoprora mongolfieri (Ehrenberg) in Nigrini, 1977, p. 250, pl. 4, figs. 1, 2.

Dictyoprora urceolus (Haeckel). Dictyocephalus urceolus Haeckel, 1887, p. 1305. Dictyoprora urceolus (Haeckel) in Nigrini, 1977, p. 251, pl. 4, figs. 9-10.

Didymocyrtis antepenultima (Riedel and Sanfilippo). Ommatartus antepenultimus Riedel and Sanfilippo, 1970, p. 521, pl. 14, fig. 4. Didymocyrtis antepenultima (Riedel and Sanfilippo) in Sanfilippo and Riedel, 1980, p. 1010, text-fig. 1.

Didymocyrtis avita (Riedel). Panartus avitus Riedel, 1953, p. 808, pl. 84, fig. 7. Didymocyrtis avita (Riedel) in Sanfilippo and Riedel, 1980 , p. 1010 , text-fig. 1.

Didymocyrtis laticonus (Riedel). Cannartus laticonus Riedel, 1959, p. 291, pl. 1, fig. 5. Didymocyrtis laticonus (Riedel) in Sanfilippo and Riedel, 1980, p. 1010, text-fig. 1, e.

Didymocyrtis penultima (Riedel). Panarium penultimum Riedel, 1957, p. 76, pl. 1, fig. 1. Didymocyrtis penultima (Riedel) in Sanfilippo and Riedel, 1980, p. 1010, text-fig. 1, f.

Didymocyrtis tetrathalamus (Haeckel). Panartus tetrathalamus Haeckel, 1887 , p. 378 , pl. 40 , fig. 3. Didymocyrtis tetrathalamus (Haeckel) in Sanfilippo and Riedel, 1980, p. 1010, text-fig. 1, g.

Druppatractus irregularis Popofsky, 1912, p. 114, text-figs. 24-26.

Eucecryphalus petrushevskaae Caulet, 1979, p. 131, pl. 2, fig. 3.

Eucyrtidium anomalum (Haeckel). Lithocampe anomala Haeckel, 1860 , p. 839. Eucyrtidium anomalum (Haeckel) in Haeckel, 1862, p. 323 , pl. 7 , figs. 11-13.

Eucyrtidium cienkowskii Haeckel gr. Eucyrtidium cienkowskii Haeckel, 1887 , p. 1493 , pl. 80 , fig. 9.

Eucyrtidium indiensis Caulet, 1979, p. 134, pl. 4, fig. 5.

Eucyrtidium punctatum (Ehrenberg). Lithocampe punctata Ehrenberg, 1844 b, p. 84. Eucyrtidium punctatum (Ehrenberg) Ehrenberg, 1847 , p. $43 ; 1854$ c, pl. 22 , fig. 24.

Haliometta miocenica (Campbell and Clark). Heliosphaera miocenica Campbell and Clark, 1944, p. 16, pl. 2, figs. 10-14. Haliometta miocenica (Campbell and Clark) in Petrushevskaya and Koslova, 1972, p. 517, pl. 9, figs. 8, 9 .

Hexacontium hootsi Campbell and Clark, 1944, p. 14, pl. 2, fig. 5.

Hexacontium medusa (Ehrenberg) $\mathrm{n}$. comb. Haliomma medusa Ehrenberg, 1854b, pl. 20, figs. 21, 22, 23, pl. 21, fig. 53, pl. 22, fig. 33.

Lamprocyclas hannai (Campbell and Clark) n. comb. Calocyclas hannai Campbell and Clark, 1944, p. 48, pl. 69, figs. 21, 22.

Lamprocyclas junonis (Haeckel) n. comb. Theoconus junonis Haeckel, 1887, p. 1401, pl. 69, fig. 7.

Lamprocyclas margatensis $\mathrm{n}$. comb. Calocyclas margatensis Campbell and Clark, 1944, p. 47, pl. 6, figs. 17-18.

Lamprocyclas maritalis Haeckel, 1887, p. 1390, pl. 74, figs. 13, 14.

Lamprocyrtis heteroporos (Hays). Lamprocyclas heteroporos Hays, 1965 , p. 179, pl. 3, fig. 1. Lamprocyrtis heteroporos (Hays) in Kling, 1973, p. 639, pl. 5, figs. 19-21, pl. 15, figs. 4, 5.

Lamprocyrtis neoheteroporos Kling. Lamprocyrtis neoheteroporos Kling, 1973 , p. 639 , pl. 5 , figs. 17,18 , pl. 15 , figs. $4,5$. 
Lamprocyrtis nigriniae (Caulet). Conarachnium nigriniae Caulet, 1971, p. 3, pl. 3, figs. 1-4, pl. 4, figs. 1-4. Lamprocyrtis nigriniae (Caulet) in Kling, 1977, p. 217, pl. 1, fig. 17.

Liriospyris ovalis Goll, 1968, p. 1429, pl. 176, figs. 4, 6, 7; text-fig. 9. Lithapium mitra (Ehrenberg) Cornutella mitra Ehrenberg, 1873, p. 221; 1875, pl. 2, fig. 8. Lithapium (?) mitra (Ehrenberg) in Riedel and Sanfilippo, 1970 , p. 520 , pl. 4, figs. 6, 7.

Lithomelissa ehrenbergi Bütschli, 1882, p. 519, pl. 33, fig. 21.

?Lithomelissa haeckeli Bütschli, 1882, p. 519, pl. 33, fig. 23.

Lithomelissa ultima Caulet, 1979, p. 129, pl. 1, figs. 2, 3.

Lithomitrella acephala (Ehrenberg). Eucyrtidium acephalum Ehrenberg, 1875, p. 70, pl. 11, fig. 5. Lithomitrella acephala (Ehrenberg) in Petrushevskaya, 1979, p. 150, figs. 380, 409.

Lithomitrella elizabethae (Clark and Campbell) n. comb. Lithomitra elizabethae Clark and Campbell, 1942, p. 92, pl. 9, fig. 18.

Lithomitrella minuta (Clark and Campbell). Lithocampe minuta Clark and Campbell, 1942, p. 93, pl. 9, fig. 17. Lithomitrella minuta (Clark and Campbell) in Petrushevskaya, 1979, p. 154, figs. 412, $413,478$.

Lithopera neotera Sanfilippo and Riedel, 1970, p. 454, pl. 1, figs. 2426, 28.

Lonchosphaera spicata Popofsky, 1908, p. 218, pl. 24, fig. 2, pl. 25, figs. 2, 7.

Lophocyrtis biaurita (Ehrenberg) gr. Eucyrtidium biaurita Ehrenberg, 1873 , p. $226 ; 1875$, pl. 70 , pl. 10, fig. 7, 8. Lophocyrtis biaurita (Ehrenberg) in Foreman, 1973, p. 442, pl. 8, figs. 23-26.

Lophocyrtis (?) jacchia. Thyrsocyrtis jacchia Ehrenberg, 1873, p. 261; 1875 , p. 84, pl. 12, fig. 7. Lophocyrtis (?) jacchia (Ehrenberg) in Riedel and Sanfilippo, 1970, p. 530; 1971, pl. 36, figs. 4, 5.

Lophophaena cylindrica (Cleve). Dictyocephalus cylindricus Cleve, 1900 , p. 7, pl. 4, fig. 10. Lophophaena cylindrica (Cleve) in $\mathrm{Pe}-$ trushevskaya, 1971, p. 117, fig. 57, V; fig. 61, IV-VI.

Lophophaena hispida (Ehrenberg). Dictyocephalus hispidus Ehrenberg, 1872 b, p. 289, pl. 5, fig. 18. Lophophaena hispida (Ehrenberg) in Petrushevskaya, 1971 , p. 115, fig. 61, I-III.

Lychnocanium grande Campbell and Clark, 1944, p. 42, pl. 6, figs. 3-6.

Lychnocanium tripodium Ehrenberg, 1875, pl. 7, fig. 2.

Lychnocanoma amphitrite Foreman, 1973, p. 437, pl. 11, fig. 10.

Lychnocanoma babylonis (Clark and Campbell) gr. Dictyophimus babylonis Clark and Campbell, 1942, p. 67, pl. 9, figs. 32, 36. Lychnocanoma babylonis (Clark and Campbell) gr. in Foreman, 1973. p. 437 , pl. 2 , fig. 1 .

Lychnocanoma bellum (Clark and Campbell). Lychnocanium bellum Clark and Campbell, 1942, p. 72, pl. 9, figs. 35, 39. Lychnocanoma bellum (Clark and Campbell) in Foreman, 1973, pl. 1, fig. 17, pl. 11, fig. 9.

Periphaena decora Ehrenberg, 1873, p. 246; 1875, pl. 28, fig. 6.

Periphaena heliasteriscus (Clark and Campbell). Heliodiscus heliasteriscus Clark and Campbell, 1942, p. 39, pl. 3, figs. 10, 11. Periphaena heliasteriscus (Clark and Campbell) in Sanfilippo and Riedel, 1973, p. 523, pl. 9, figs. 1-6, pl. 27, fig. 8.

Phormostichoartus corbula (Harting). Lithocampe corbula Harting, 1863, p. 12, pl. 1, fig. 21. Phormostichoartus corbula (Harting) in Nigrini, 1977, p. 252, pl. 1, fig. 10.

Phormostichoartus doliolum (Riedel and Sanfilippo). Artostrobium doliolum Riedel and Sanfilippo, 1971, p. 1599, pl. 1H, figs. 1-3, pl. 8, figs. 14, 15. Phormostichoartus doliolum (Riedel and Sanfilippo) in Nigrini, 1977, p. 252, pl. 1, fig. 14.

Phormostichoartus fistula Nigrini, 1977, p. 153, pl. 1, figs. 11-13.

Phormostichoartus furcaspiculata (Popofsky) n. comb. Lithamphore furcaspiculata Popofsky, 1913, p. 408, text-figs. 138, 139.

Phormostichoartus marylandicus (Martin). Lithocampe marylandica Martin, 1904, p. 450, pl. 130, fig. 4. Phormostichoartus marylandicus (Martin) in Nigrini, 1977, p. 253, pl. 2, figs. 1-3.

Phormostichoartus multiseriatus (Ehrenberg) n. comb. Eucyrticium multiseriatum Ehrenberg, 1860, p. 768. Lithocampe? multiseriate (Ehrenberg) in Petrushevskaya, 1967, p. 135, fig. 16, I-III.

Phormostichoartus platycephala (Ehrenberg) n. comb. Eucyrtidium platycephalum Ehrenberg, 1872b, pl. 3, fig. 16. Lithocampe (?) platycephala (Ehrenberg) in Petrushevskaya, 1967, p. 137, fig. 73, part; fig. 77 , part.

Platybursa clathrobursa (Haeckel). Tessarospyris clathrobursa Haeckel, 1887, p. 1051, pl. 53, fig. 7. Platybursa clathrobursa (Haeckel) in Petrushevskaya, 1971, p. 259, fig. 130, II-V.
Prunopyle hayesi Chen, 1975, p. 454, pl. 9, figs. 3-5.

Prunopyle titan Campbell and Clark, 1944, p. 20, pl. 3, figs. 1-3.

Pseudocubus vema (Hays). Helotholus vema Hays, 1965, pl. 2, fig. 3 , text-fig. A. Pseudocubus vema (Hays) in Petrushevskaya, 1971, p. 46 , fig. 24 , I-IV.

Pseudodictyophimus callosus (Petrushevskaya) n. comb. Dictyophimus callosus Petrushevskaya, 1979, p. 143, figs. 256, 257.

Pseudodictyophimus gracilipes (Bailey) gr. Dictyophimus gracilipes Bailey, 1856, p. 4, pl. 1, fig. 8. Pseudodictyophimus gracilipes (Bailey) in Petrushevskaya, 1971, p. 93, fig. 47-49.

Pterocanium prismatium Riedel, 1957, p. 87, pl. 3, figs. 4, 5.

Pterocanium trilobum (Haeckel). Dictyopodium trilobum Haeckel, 1860 , p. $839 ; 1862$, p. 340 , pl. 8 , figs. 6-10. Pterocanium trilobum (Haeckel) in Haeckel, 1887, p. 1333.

Pterocorys campanula campanula Haeckel. Pterocorys campanula Haeckel, 1887 , p. 1316, pl. 71, fig. 3. Pterocorys campanula campanula Haeckel in Caulet, 1979, p. 133, pl. 3, figs. 3, 6.

Pterocorys campanula variabilis Caulet, 1979, p. 133, pl. 3, figs. 2, 5. Pterocorys hertwigii (Haeckel). Eucyrtidium hertwigii Haeckel, 1887, p. 1491, pl. 80, fig. 12. Pterocorys hertwigii (Haeckel) in Nigrini, 1967 , p. 73 , pl. 7 , figs. 4 a, b.

Pterocorys zancleus (Müller). Eucyrtidium zancleum Müller, 1855, p. 492; 1858, p. 41, pl. 6, figs. 1-3. Pterocorys zancleus (Müller) in Petrushevskaya, 1971 , p. 233 , fig. 119 , I-VII.

Pterocyrtidium barbadense (Ehrenberg) gr. Pterocanium barbadense Ehrenberg, 1873, p. 254; 1875, pl. 17, fig. 6. Pterocyrtidium barbadense (Ehrenberg) in Petrushevskaya, 1972, p. 352, pl. 27, figs. $18,19$.

Rhizosphaera antarcticum (Haeckel) n. comb. Spongoplegma antarctica Haeckel, 1887, p. 90.

Saccospyris antarctica Haecker, 1907, p. 124; 1908, p. 447, pl. 84, figs. $584,589,590$.

Saccospyris preantarctica Petrushevskaya, 1975, p. 589, pl. 13, figs. $19,20$.

Siphocampe modeloensis (Campbell and Clark) n. comb. Lithocampe modeloensis Campbell and Clark, 1944, p. 59, pl. 7, figs. 28-30.

Siphostichartus corona (Haeckel). Cyrtophormis (Acanthocyrtis) corona Haeckel, 1887, p. 1462, pl. 77, fig. 15. Siphostichartus coro$n a$ (Haeckel) in Nigrini, 1977, p. 257, pl. 2, figs. 5, 6, 7.

Solenosphaera omnitubus omnitubus Riedel and Sanfilippo, 1971, p. 1586, pl. 1A, fig. 24, pl. 4, figs. 1, 2.

Spirocyrtys gyroscalaris Nigrini, 1977, p. 258, pl. 2, figs. 10, 11.

Spirocyrtis scalaris Haeckel, 1887, p. 1509, pl. 76, fig. 14.

Spirocyrtis subscalaris Nigrini, 1977, p. 259, pl. 3, figs. 1, 2.

Spirocyrtis subtilis Petrushevskaya in Petrushevskaya and Koslova, 1972, p. 540 , pl. 24 , figs. $22-24$.

Spongaster berminghami (Campbell and Clark). Spongasteriscus berminghami Campbell and Clark, 1944, p. 30, pl. 5, figs. 1, 2. Spongaster berminghami (Campbell and Clark) in Riedel and Sanfilippo, 1978, p. 73, pl. 2, figs. 14-16.

Spongaster pentas Riedel and Sanfilippo, 1970, p. 523, pl. 15, fig. 3.

Spongaster tetras Ehrenberg, 1860, p. 833.

Spongotrochus glacialis Popofsky, 1908, p. 228, pl. 26, fig. 8, pl. 27, fig. 1, pl. 28, fig. 2.

Stauroxiphos communis Carnevale, 1908, p. 15, pl. 2, fig. 9.

Stichocorys delmontensis (Campbell and Clark). Eucyrtidium delmontense Campbell and Clark, 1944, p. 56, pl. 7, figs. 19, 20. Stichocorys delmontensis (Campbell and Clark) in Sanfilippo and Riedel, 1970, p. 451, pl. 1, fig. 9.

Stichocorys peregrina (Riedel). Eucyrtidium elongatum peregrinum Riedel, 1953, p. 812, pl. 85, fig. 2. Stichocorys peregrina (Riedel) in Sanfilippo and Riedel, 1970, p. 451, pl. 1, fig. 10.

Stichopodium biconicum (Vinassa). Lithocampe biconica Vinassa, 1900, pl. 3, fig. 30. Stichopodium biconicum (Vinassa) in Petrushevskaya, 1975 , p. 581 , pl. 14 , figs. $25-27$, pl. 22, fig. 7.

Stichopodium calvertense (Martin). Eucyrtidium calvertense Martin, 1904 , p. 450, pl. 130, fig. 5. Stichopodium calvertense (Martin) in Petrushevskaya and Kozlova, 1972, pl. 26, figs. 9, 10.

Stichopodium inflatum (Kling). Eucyrtidium inflatum Kling, 1973, p. 636 , pl. 11, figs. $7,8, \mathrm{pl}$. 15, fig. 7-10. Stichopodium inflatum (Kling) in Petrushevskaya, 1975, p. 581, pl. 26, figs. 7, 8.

Stylatractus universus Hays, 1970, p. 215, pl. 1, figs. 1, 2.

Stylosphaera angelina Campbell and Clark, 1944, p. 12, pl. 1, figs. $15,20$.

Stylosphaera minor Clark and Campbell, 1942, p. 27, pl. 5, figs. 1, 2. 
Theocalyptra bicornis (Popofsky). Pterocorys bicornis Popofsky, 1908, p. 228, pl. 34, figs. 7, 8. Theocalyptra bicornis (Popofsky) in Riedel, 1958 , p. 240 , pl. 4 , fig. 4.

Theocalyptra davisiana (Ehrenberg). Cycladophora ? davisiana Ehrenberg, 1861, p. 297. Theocalyptra davisiana (Ehrenberg) in Riedel, 1958, p. 239, pl. 4, figs. 2, 3, text-fig. 10.

Theocorys cretica (Ehrenberg) gr. Eucyrtidium creticum Ehrenberg, 1857 , p. 559; 1872b, pl. 11, fig. 23. Theocorys cretica (Ehrenberg) in Haeckel, 1887, p. 1415.

Theocorys spongoconum (Kling). Thecocorys spongoconus Kling, 1971, pl. 5, fig. 6. Theocorys spongoconum Kling in Riedel and Sanfilippo, 1971 , pl. 2 F, fig. 4 , pl. $3 \mathrm{C}$, fig. 3 .

Theocorythium vetulum Nigrini, 1971, p. 447, pl. 34.1, figs. 6a, $6 \mathrm{~b}$.

Thyrsocyrtis bromia Ehrenberg, 1873, p. 260; 1875, p. 84, pl. 12, fig. 2.

Triceraspyris antarctica (Haecker). Phormospyris antarctica Haecker, 1907, p. 124, fig. 9. Triceraspyris antarctica (Haecker) in Haecker, 1908 , p. 445 , pl. 84 , fig. 586.

Tricolocapsa bergontiana (Carnevale) gr. n. comb. Dictyocephalus bergontianum Carnevale, 1908, p. 32, pl. 4, fig. 20.

Tricolospyris baconiana variabilis (Goll) $\mathrm{n}$. comb. Tholospyris baconiana variabilis Goll, 1972, p. 452, pl. 8, figs. 1-8, pl. 9, figs. 112.

Tricolospyris newtoniana Haeckel, 1887, p. 1098, pl. 88, fig. 11.

Tripodiscinus clavipes (Clark and Campbell). Tripilidium clavipes Clark and Campbell, 1942, p. 64, pl. 9, fig. 29. Tripodiscinus clavipes (Clark and Campbell) in Petrushevskaya, 1979, p. 115, fig. 302.

Tristylospyris triceros (Ehrenberg). Ceratospyris triceros Ehrenberg, 1873 , p. 220 ; 1875 , pl. 21, fig. 5. Tristylospyris triceros (Ehrenberg) in Haeckel, 1887, p. 1033.

Velicucculus magnificum (Clark and Campbell). Soreuma magnificum Clark and Campbell, 1942, p. 51, pl. 4, fig. 15.

\section{ACKNOWLEDGMENTS}

Financial support for this study was provided by CNRS grant ATP no. 98.1012 . The samples were kindly made available by the shipboard party. The author is much indebted to Catherine Nigrini who offered innumerable suggestions and kindly reviewed the structure of many sentences. Thanks are due to J. P. Kennett and F. M. Weaver for the critical review of the manuscript and to W. R. Riedel and A. Sanfilippo for informative discussions. The interest and support of Y. Lancelot and $\mathrm{H}$. Chamley have also been of great value. A. Maurs, M. Destarac and A. Cambreleng assisted with photography and illustrations.

\section{REFERENCES}

Bailey, J. W., 1856. Notice of microscopic forms found in the soundings of the Sea of Kamtschatka-with a plate. Am. J. Sci. Arts, Ser. 2, 22:1-6.

Bjørklund, K. R., and Goll, R. M., 1979. Internal skeletal structures of Collosphaera and Trisolenia: a case of repetitive evolution in the Collosphaeridae (Radiolaria). J. Paleontol., 53(no. 6):1293-1326.

Bütschli, O., 1882. Beiträge zur Kenntnis des Radiolarienskelette, insbesondere der Cyrtida. Z. Wiss. Zool., 36:485-540.

Campbell, A. S., and Clark, B. L., 1944. Miocene Radiolarian Faunas from Southern California. Geol. Soc. Am., Spec. Pap. No. 51.

Carnevale, P., 1908. Radiolarie e Silicoflagellati di Bergonzano (Reggio Emilia). Mem. R. Ist. Veneto Sci. Lett. Arti, 28(no. 3):1-46.

Caulet, J. P., 1971. Contribution à l'étude de quelques radiolaires nassellaires des boues de la Méditerranée et du Pacifique. Cah. Micropaléontol., Ser. 2, 10:1-10.

1977. La silice biogène dans les sédiments néogènes et quaternaires de l'océan indien austral. Bull. Soc. Geol. France, 19(no. 5):1021-1032.

, 1979. Les dépôts à Radiolaires d'âge pliocène supérieur à pléistocène dans l'océan indien central: nouvelle zonation biostratigraphique. Recherches Océanographiques dans l'Océan Indien. Paris 20-22 Juin 1977. Mem. Mus. Nat. Hist. Nat. Ser. C, 43:119-141.

1982. Faunes de radiolaires et fluctuations climatiques dans les sédiments de l'océan indien austral: une nouvelle biozonation. Bull. Soc. Geol. France, 24(no. 3):555-562.

Chen, P.-H., 1975. Antarctic radiolaria. In Hayes, D. E., Frakes, L. A., et al., Init. Repts. DSDP, 28: Washington (U.S. Govt. Printing Office), 437-513.
Clark, B. L., and Campbell, A. S., 1942. Eocene Radiolarian Faunas from the Monte Diablo Area, California. Geol. Soc. Am. Spec. Pap. No. 39.

Cleve, P. T., 1900. Notes on some Atlantic plankton-organisms. Handl. Kgl. Svenska Vetensk.-Akad., 34(no. 1):1-22.

Dumitrica, P., 1973. Cretaceous and Quaternary Radiolaria in deep sea sediments from the northeast Atlantic Ocean and Mediterranean Sea. In Ryan, W. B. F., Hsü, K. J., et al., Init. Repts. DSDP, 13, Pt. 2: Washington (U.S. Govt. Printing Office), 829-901.

Ehrenberg, C. G., 1840. (Characteristik von 274 neuen Arten von Infusorien). Uber die auffalend rasche Entwicklung dieser Kenntnisse. K. Preuss. Akad. Wiss. Berlin, Ber., 1840:197-219.

1844a. Einige vorläufige Resultate seiner Untersuchungen der ihm von der Südpolreise des Capitain Ross, so wie von den Herren Schayer und Darwin zugekommen Materialen über das Verhalten des kleinsten Lebens in den Oceanen und den grössten bisher zugänglichen Tiefen des Weltmeeres. K. Preuss. Akad. Wiss. Berlin, Monatsber., 1844:182-207.

, 1844b. Uber 2 neue Lager von Gebirgsmassen aus Infusorien als Meeres-Absatz in Nord-Amerika und eine Vergleichung derselben mit den organischen Kreide-Gebilden in Europa und Afrika. K. Preuss. Akad. Wiss. Berlin, Ber., 1844:57-97.

1847. Uber die mikroskopischen kieselschaligen Polycystinen als mächtige Gebirgsmasse von Barbados und über das Verhältniss der aus mehr als 300 neuen Arten bestehenden ganz eigenthümlichen Formengruppe jener Felsmasse zu den jetzt legenden Thieren und zur Kriedebildung eine eue Anregung zur Erforschung des Erdlebens. K. Preuss. Akad. Wiss. Berlin, Ber., 1847:40-60.

1854a. Die systematische Charakteristik der neuen mikroskopischen Organismen des tiefen atlantischen Oceans. K. Preuss. Akad. Wiss. Berlin, 1854:236-250.

1854b. Mikrogeologie: Leipzig (Leopold Voss).

1854c. Uber das organische Leben des Meeresgrundes in bis 10800 und 12000 Fuss Tiefe. K. Preuss. Akad. Wiss. Berlin, Monatsber., 1854:54-75.

1857. Uber die organischen Lebensformen in unezwartet grossen Tiefen des Mittelmeeres. K. Preuss. Akad. Wiss. Berlin, Monatsber., 1857:538-570.

1860. Uber den Tiefgrund des stillen Oceans zwischen Californien und den Sandwich-Inseln aus bis 15600 Tief nach Lieut. Brooke. K. Preuss. Akad. Wiss. Berlin, Monatsber., 1860:819-833. 1861, Uber die Tiefgrund-Verhältnisse des Oceans am Einegange des Davisstrasse und bei Island. K. Preuss. Akad. Wiss. Berlin, Monatsber., 1861:275-315.

1872a. Mikrogeologischen Studien als Zusammenfassung der Beobachtungen des kleinsten Lebens des Meeres-Tiefgrunde aller Zonen und dessen geologischen Einfluss. K. Preuss. Akad. Wiss. Berlin, Monatsber., 1872:265-322.

$1872 \mathrm{~b}$. Mikrogeologischen Studien über das kleinste Leben der Meeres-Tiefgrunde aller Zonen und dessen geologischen Einfluss. K. Preuss. Akad. Wiss. Berlin, Abhandl., 1872:131-399. 1873. Grössere Felsproben des Polycystinen-Mergels von Barbados mit weiteren Erläuterungen. K. Preuss. Akad. Wiss. Berlin, Monatsber., 1873:213-263.

1875. Fortsetzung der mikrogeologischen Studien als Gesammt-Uebersicht der mikroskopischen Paläeontologie gleichartig analysirter Gebirgsarten der Erde, mit specieller Rücksicht auf den Polycystinen-Mergel von Barbados. K. Preuss. Akad. Wiss. Berlin, Abhandl., 1875:1-226.

Foreman, H. P., 1973. Radiolaria of Leg 10 with systematics and ranges for the families Amphypindacidae, Artostrobiidae, and Theoperidae. In Worzel, J. L., Bryant, W., et al., Init. Repts. DSDP, 10: Washington (U.S. Govt. Printing Office), 407-474.

Goll, R. M., 1968. Classification and phylogeny of Cenozoic Trissocyclidae (Radiolaria) in the Pacific and Caribbean basins. Part I. J. Paleontol., 42(no. 6):1409-1432.

, 1969. Classification and phylogeny of Cenozoic Trissocyclidae (Radiolaria) in the Pacific and Caribbean Basins. J. Paleontol., 43(no. 2):322-339.

1972. Systematics of eight Tholospyris taxa (Trissocyclidae, Radiolaria). Micropaleontology, 18(no. 4):443-475.

Haeckel, E., 1860. Abbildungen und Diagnosen neuer Gattungen und Arten von lebenden Radiolarien des Mittelmeeres. K. Preuss. Akad. Wiss. Berlin, Monatsber., 1860:835-845. 

(Reimer).

1862. Die Radiolarien (Rhizopoda Radiolaria): Berlin

1887. Report on the Radiolaria collected by H.M.S. Challenger during the Years 1873-1876. Report on the Scientific Results of the Voyage of H.M.S. Challenger. Zoology (Vol. 18).

Haecker, V., 1907. Altertümlich Sphärellarien und Cyrtellarien aus grossen Meerestiefen. Archiv. Protistenk., 10:114-126.

1908. Tiefsee-Radiolarien. Spezieller Teil, Lfg. 2. Die Tripyleen, Collodarien und Mikroradiolarien der Tiefsee. Wiss. Ergebn. D. Tiefsee Exped. ("Valdivia"), 14:337-476.

Harting, P., 1863. Bijdrage tot de kennis der mikroskopische faune en flora van de Banda-Zee. Verh. K. Akad. Wetensh. Amsterdam, 10: $1-34$.

Hays, J. D., 1965. Radiolaria and late Tertiary and Quaternary history of Antarctic Seas. Biology of Antarctic Seas II. Am. Geophys. Un., Antarc. Res. Ser., 5:125-184.

1970. Stratigraphy and evolutionary trends of Radiolaria in North Pacific deep-sea sediments. Geol. Soc. Am. Mem., 126: 185-218.

Johnson, D. A., 1974. Radiolaria from the eastern Indian Ocean, DSDP Leg 22. In von der Borch, C. C., Sclater, J. G., et al., Init. Repts. DSDP, 22: Washington (U.S. Govt. Printing Office), 521-575.

Johnson, T. C., 1975. The dissolution of siliceous microfossils in deep-sea sediments [Ph.D. dissert.]. University of California, San Diego.

Jørgensen, E., 1900. Protophyten und Protozoen im Plankton aus der norwegischen Westküste. Bergens Museums Aarbog. (1899), no. 2, (no.6):1-112.

1905. The protist plankton and the diatoms in bottom samples. Bergens Mus. Skr., pp. 49-151, 195-225.

Kling, S. A., 1971. Radiolaria. Leg 6 of the Deep Sea Drilling Project. In Fischer, A. G., Heezen, B. C., et al., Init. Repts. DSDP, 6: Washington (U.S. Govt. Printing Office), 1069-1117.

1973. Radiolaria from the eastern North Pacific, Deep Sea Drilling Project Leg 18: In Klum, L. D., von Huene, R., et al., Init. Repts. DSDP, 18: Washington (U.S. Govt. Printing Office), 617-671.

1977. Local and reigonal imprints on radiolarian assemblages from California coastal basin sediments. Mar. Micropaleontol., 2(no. 2):207-221.

Knoll, A. H., and Johnson, D. A., 1975. late Pleistocene evolution of the collosphaerid radiolarian Buccinosphaera invaginata Haeckel. Micropaleontology, 21(no. 1):60-68.

Martin, G. C., 1904. Radiolaria: Baltimore (Maryland Geological Survey and John Hopkins Press).

Maurrasse, F., and Glass, B., 1976. Radiolarian stratigraphy and North American microtektites in Caribbean RC9-58: implications concerning late Eocene radiolarian chronology and the age of the Eocene-Oligocene boundary. Publ. de la VII Conf. Géol. des Caraibes (30 Juin au 12 Juillet 1974), Cayenne, pp. 205-212.

Moore, T. C., Jr., 1972. Mid-tertiary evolution of the radiolarian genus, Calocycletta. Micropaleontology, 18(no. 2):244-252.

Müller, J., 4855. Uber Sphaerozoum und Thallassicolla. K. Preuss. Akad. Wiss. Berlin, Monatsber., 1855:229-253.

1858. Uber die Thalassicollen, Polycystinen und Acanthometren des Mittelmeeres. K. Preuss. Akad. Wiss. Berlin, Abhandl., 1858:1-62.

Nakaseko, K., 1963. Neogene Cyrtoidea (Radiolaria) from the Isozaki Formation in Ibaraki Prefecture, Japan. Sci. Rep. Coll. Gen. Ed., Osaka Univ., 12(no. 2):165-198.

Nigrini, C. A., 1967. Radiolaria in Pelagic Sediments from the Indian and Atlantic Oceans. Bull. Scripps Inst. Oceanogr., 11.

1971. Radiolarian zones in the Quaternary of the equatorial Pacific Ocean. In Funnell, B. M., and Riedel, W. R. (Eds.), The Micropaleontology of Oceans: Cambridge (Cambridge University Press), pp. 443-461.

1977. Tropical Cenozoic Artostrobiidae (Radiolaria), Micropaleontology, 23(no. 3):241-269.

Nigrini, C. A., and Moore, T. C., Jr., 1979. A Guide to Modern Radiolaria. Cushman Found. Foraminiferal Res. Spec. Publ., 16.

Petrushevskaya, M. G., 1965. Osobennosti i konstruktsii skeleta radiolaryii Botryoidae (otr. Nassellaria). Trudy Zool. Inst., 35:79118.

1967. Radiolarii otryadov spumellaria i nassellaria antarkticheskoi oblasti (po materialam sovetsko, antarkticheskoi ekspe- ditsii). Issled. Fauny. morei, 4(12). Resultaty Biol. Issled. Sovetskoi Antarktic Eksped. (1950-1958), vyp. 3.

1971. Radiolarians of the ocean. Explorations of the Faune of the Seas, 9(17), Acad. Sci. USSR, Zool. Inst., Leningrad, 1971. (In Russian.)

1972. Biostratigraphy of deep-sea Quaternary sediments based on the radiolarian analysis data. Okeanologia, 12:71-86. 1975. Cenozoic radiolarians of the Antarctic, Leg 29, DSDP.

In Kennett, J. P., Houtz, R. E., et al., Init. Repts. DSDP, 29: Washington (U.S. Govt. Printing nffice), 541-675

1979. The history of the microplankton of the Norwegian Sea. Explorations of the Fauna of the Seas, 23(31), Acad. Sci USSR, Zool. Inst. Leningrad, 1979. (In Russian.)

Petrushevskaya, M. G., and Koslova, G. E., 1972. Radiolaria: Leg 14, Deep Sea Drilling Project. In Hayes, D. E., Pimm, A. C., et al., Init. Repts. DSDP, 14: Washington (U.S. Govt. Printing Office), 495-648.

Popofsky, A., 1908. Die Radiolarien der Antarktis (mit Ausnahme der Tripyleen). D. Süd-Polar Exped. 1901-1903, Rept. 10 (Zool., Vol. 2) (pt. 3):183-305.

1913. Die Nassellarien des Warmwassergebietes. D. Südpolar-Exped. 1901-1903, Rept., 14(Zool., Vol. 6)(no.1):217-416.

Riedel, W. R., 1953. Mesozoic and late Tertiary Radiolaria of Rotti. $J$. Paleontol. 27(no. 6):805-813. 1957. Radiolaria. A preliminary stratigraphy. Repts. Swed. Deep-Sea Exped. 1947-1948, 6(no. 3):59-96.

, 1958. Radiolaria in antarctic sediments. Repts. B.A.N.Z. Antarctic Res. Exped., Ser. B, 6(10):217-255. 1959. Oligocene and lower Miocene Radiolaria in tropical Pacific sediments. Micropaleontology, 5(no. 3):285-302.

1967. Subclass Radiolaria. In Harland, W. B., et al. (Eds.), The Fossil Record: London (Geol. Soc. London), pp. 291-298.

Riedel, W. R., and Sanfilippo, A., 1970. Radiolaria, Leg 4, Deep Sea Drilling Project. In Bader, R. G., Gerard, R. D., et al., Init. Repts. DSDP, 4: Washington (U.S. Govt. Printing Office), 503-575.

1971. Cenozoic Radiolaria from the western tropical Pacific, Leg 7. In Winterer, E. L., Riedel, W. R., et al., Init. Repts. DSDP, 7, Pt. 2: Washington (U.S. Govt. Printing Office), 1529-1672.

1978. Stratigraphy and evolution of tropical Cenozoic radiolarians. Micropaleontology, 24(no. 1):61-96.

Riedel, W. R., Sanfilippo, A., and Cita, M. B., 1974. Radiolarians from the stratotype Zanclean (Lower Pliocene, Sicily). Rev. Ital. Paleontol. Stratigr., 80(no. 4):699-734.

Riedel, W. R., and Westberg, J., 1982. Neogene radiolarians from the eastern tropical Pacific and Caribbean, DSDP Leg 68. In Prell, W. L., Gardner, J. V., et al., Init. Repts. DSDP, 68: Washington (U.S. Govt. Printing Office), 289-300.

Sanfilippo, A., and Riedel, W. R., 1970. Post-Eocene "closed" theoperid radiolarians. Micropaleontology, 16(no. 4):446-462.

1973. Cenozoic Radiolaria (exclusive of Theoperids, Artostrobiids and Amphipyndacids) from the Gulf of Mexico, DSDP Leg 10. In Worzel, J. L., Bryant, W., et al., Init. Repts. DSDP, 10: Washington (U.S. Govt. Printing Office), 475-612.

1980. A revised generic and suprageneric classification of the Artiscins (Radiolaria). J. Paleontol., 54(no. 5):1008-1011.

Sanfilippo, A., Burckle, L. H., Martini, E., and Riedel, W. R., 1973. Radiolarians, diatoms, silicoflagellates and calcareous nannofossils in the Mediterranean Neogene. Micropaleontology, 19(no. 2): 209-234.

Saunders, J. B., Bernoulli, D., Müller-Merz, E., Oberhänsli, H., PerchNielsen, K., Riedel, W. R., Sanfilippo, A., and Torrini, R., Jr., in press. Stratigraphy of the late-middle Eocene to early Oligocene in the Bath Cliff section, Barbados, West Indies. Micropaleontology.

Stöhr, E., 1880. Die Radiolarienfauna der Tripoli von Grotte, Provinz Girgenti in Sicilien. Palaeontographica, 26(ser. 3, vol. 2):71-124.

Vinassa de Regny, P., 1900. Radiolari miocenici italiani. Mem. $R$. Acad. Sci. Ist. Bologna Ser. 5, 8:227-257.

Weaver, F. M., 1983. Cenozoic radiolarians from the southwest Atlantic, Falkland Plateau region, Deep Sea Drilling Project Leg 71. In Ludwig, W. J., Krasheninnikov, V. A., et al., Init. Repts. DSDP, 71, Pt. 2: Washington (U.S. Govt. Printing Office), 667-686.

Westberg, M. J., and Riedel, W. R., 1982. Radiolarians from the Middle America trench off Guatemala, Deep Sea Drilling Project Leg 67. In Aubouin, J., von Huene, R., et al., Init. Repts. DSDP, 67: Washington (U.S. Govt. Printing Office), 501-424. 

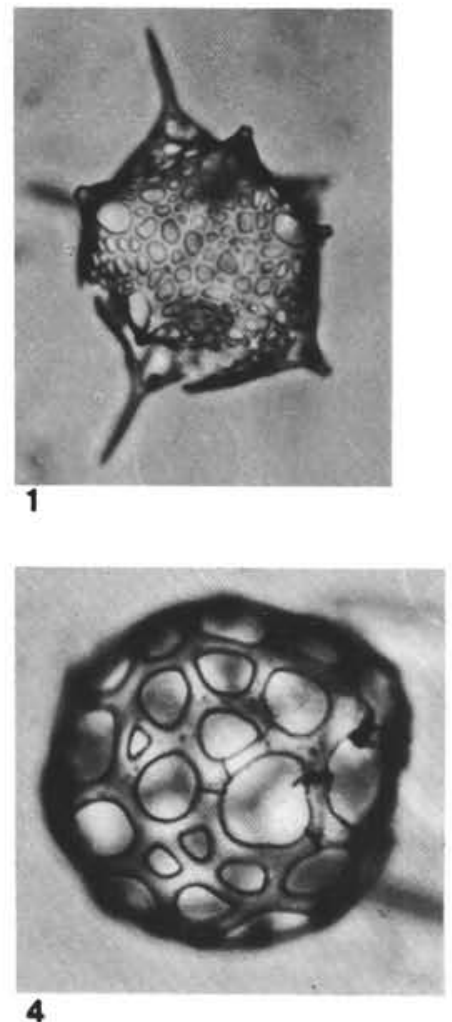

4

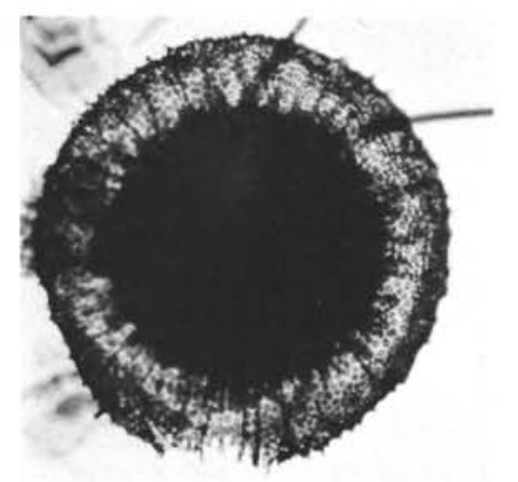

8

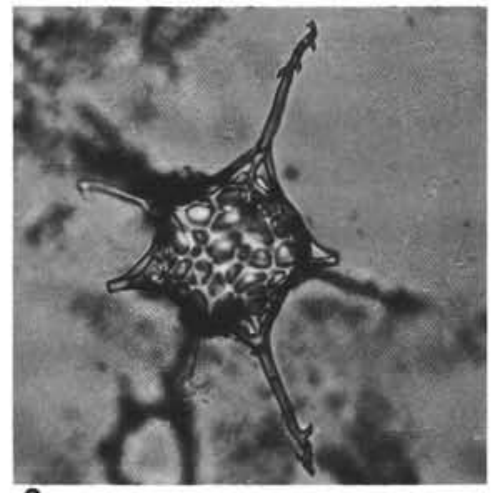

2

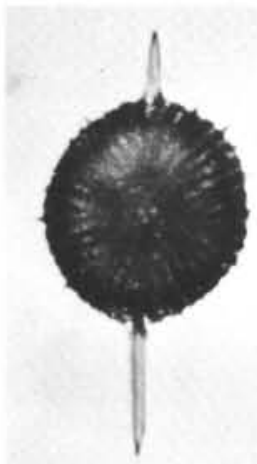

5

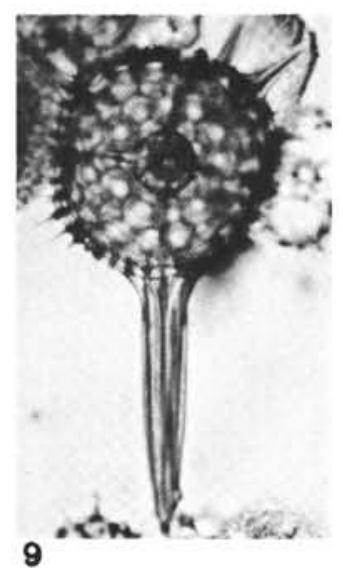

6

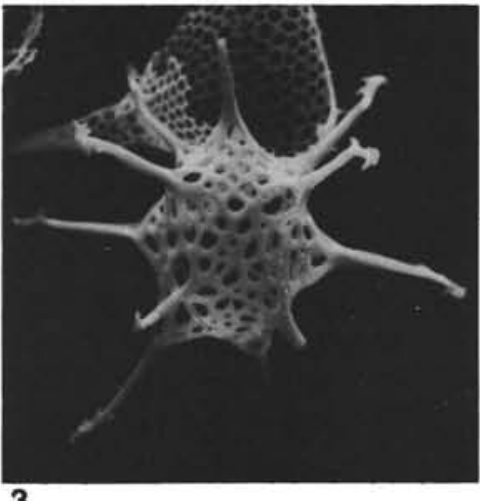

3
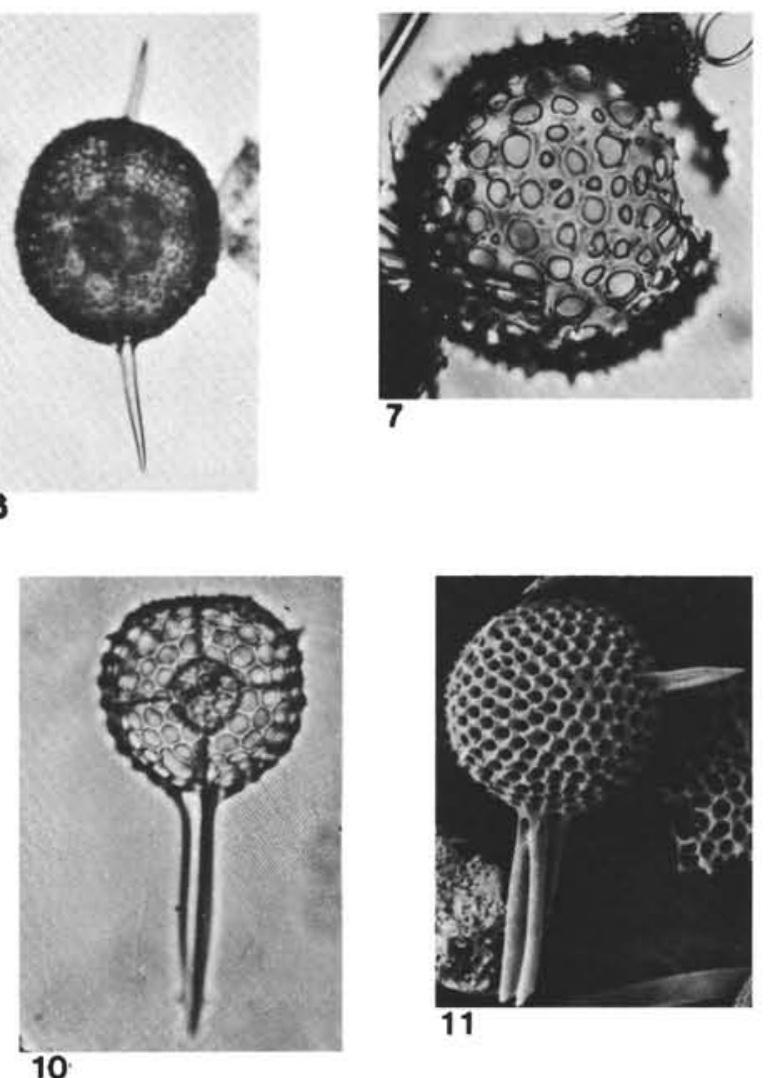

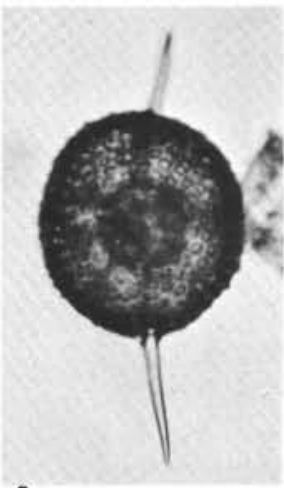



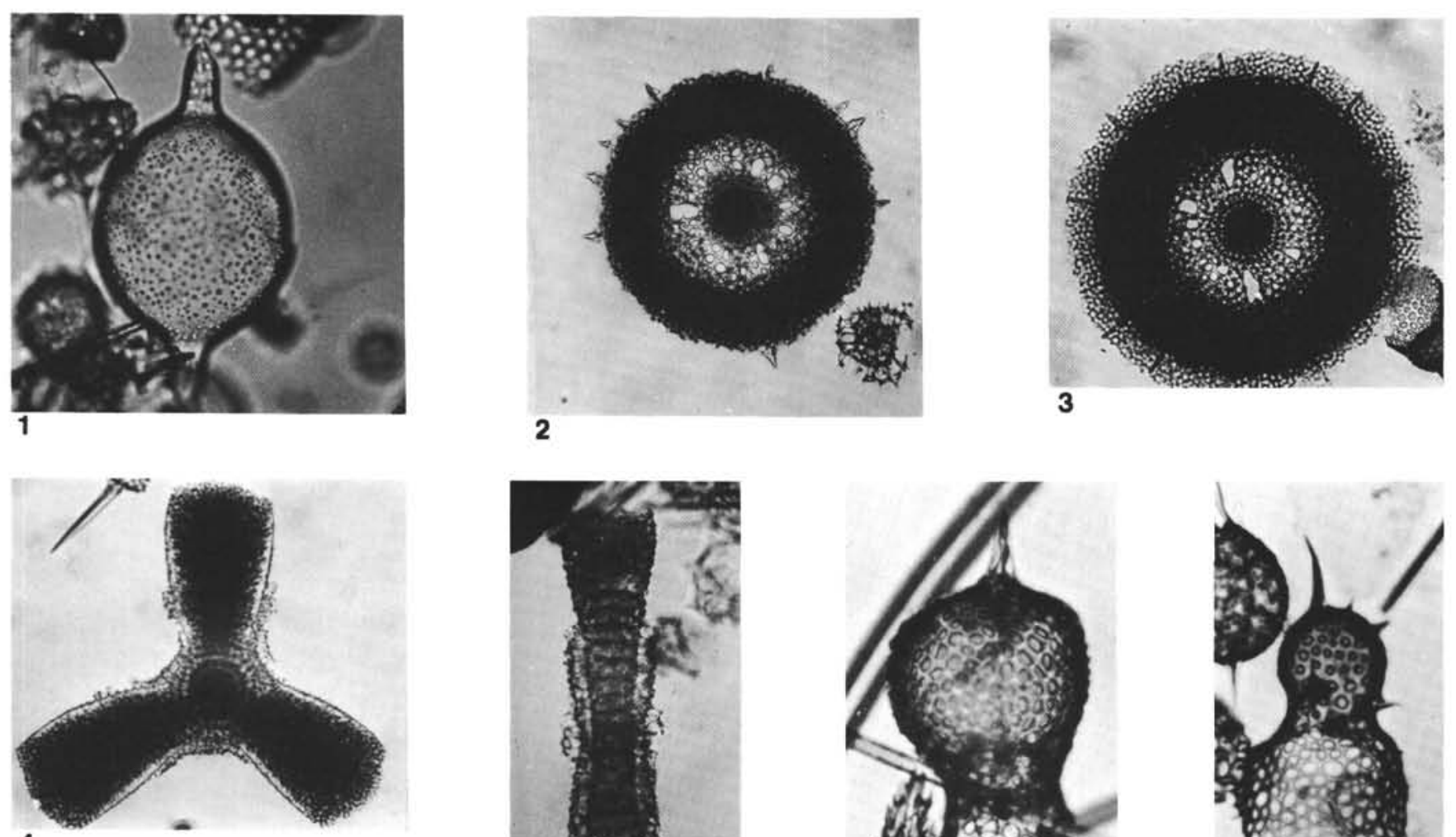

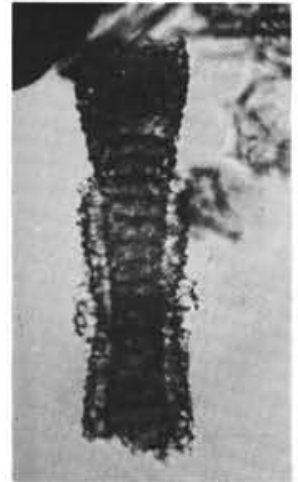

5

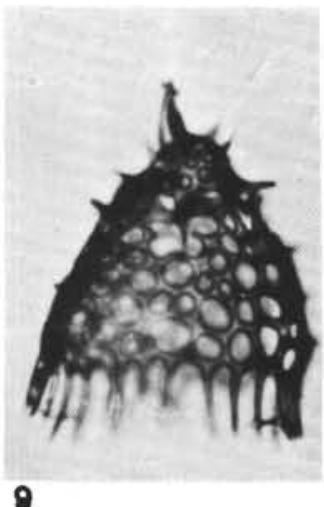

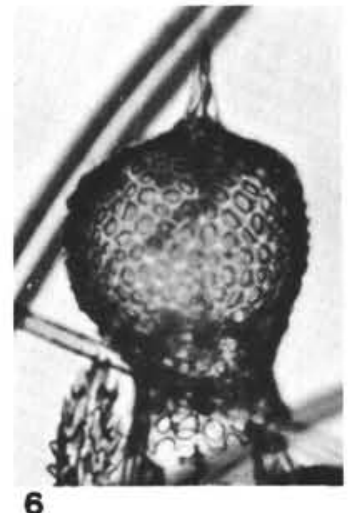

6

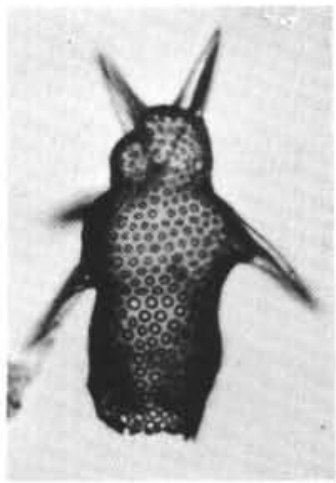

10

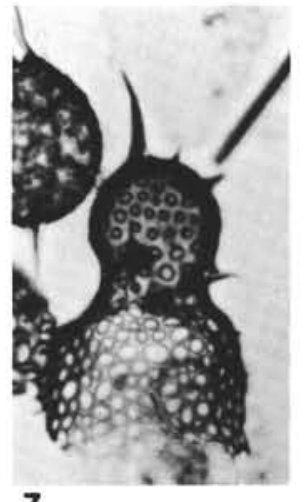

7

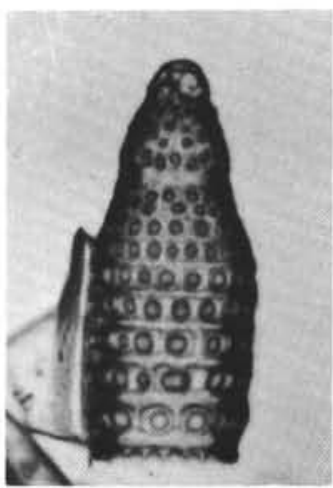

11

Plate 2. 1. Siphonosphaera hyalina, holotype, Sample 586B-6-3, 60-62 cm; $\times 300$. 2-3. Spongodiscus klingi, (2) Sample 586B-18-1, 60-62 cm; $\times 200$, (3) holotype, Sample 586B-19-3, 60-62 cm; $\times 200$. 4. Rhopalastrum oracutibrachium, holotype, Sample 586B-23-5, 60-62 cm; $\times 190$. 5. Tessarastrum sp., Sample MD $81481-\mathrm{III}-24 \mathrm{~cm} ; \times 200$. 6. Lithomelissa sp., Sample $592-40-4,40-42 \mathrm{~cm} ; \times 300$. 7. Lithomelissa ehrenbergi, Sample 594-52-2, 84-86 cm; $\times 280$. 8. Pseudodictyophimus sp., Sample $594-41-2,84-86 \mathrm{~cm} ; \times 250$. 9. Ceratocyrtis sp., Sample $594-52-2,84-86 \mathrm{~cm} ; \times 320$. 10. Nasselaria gen. et sp. indet., Sample 594-49-1, 84-86 cm; $\times 300$. 11. Siphocampe(?), Sample 594-48-2, 84-86 $\mathrm{cm} ; \times 500$. 


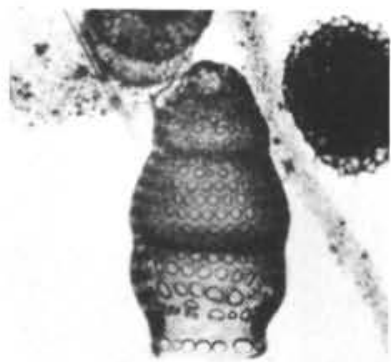

1

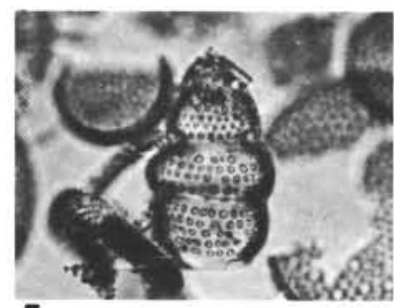

5

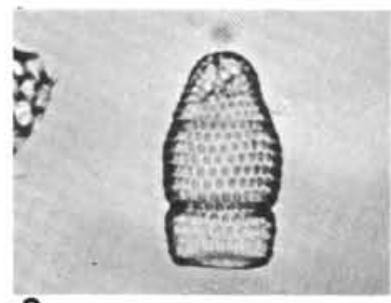

9

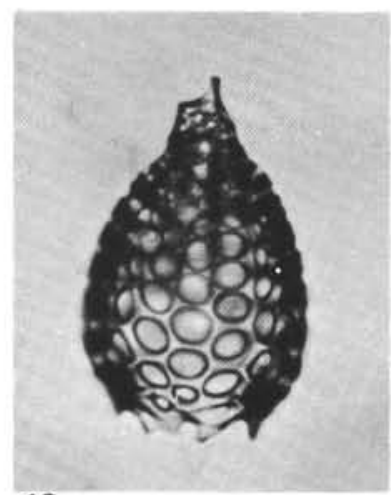

13

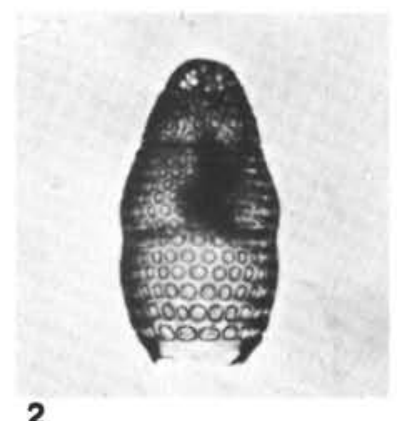

2
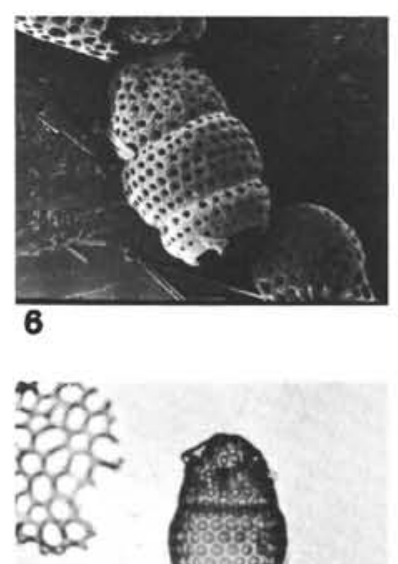

10
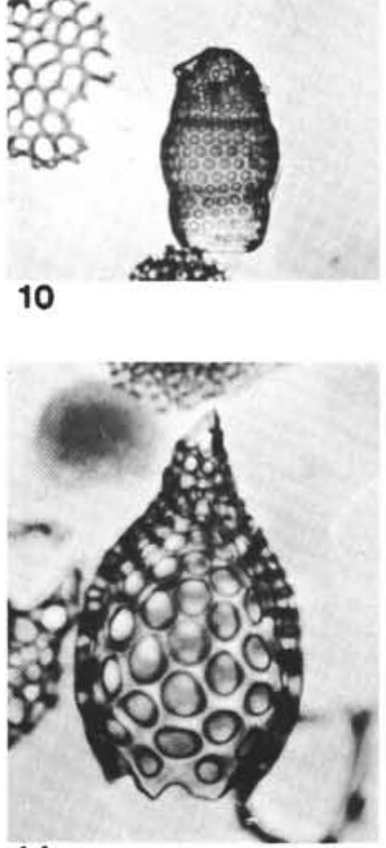

14

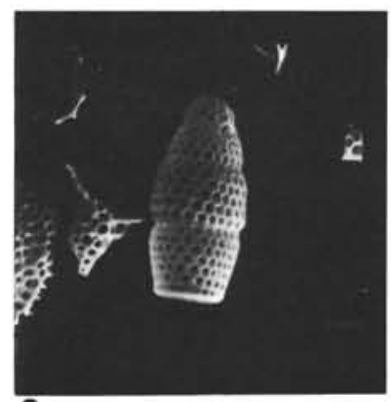

3
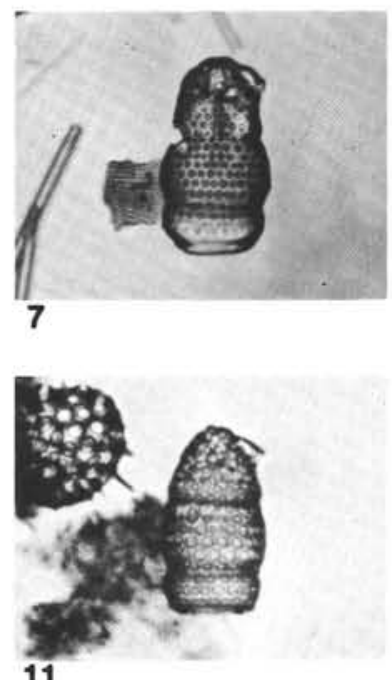

11

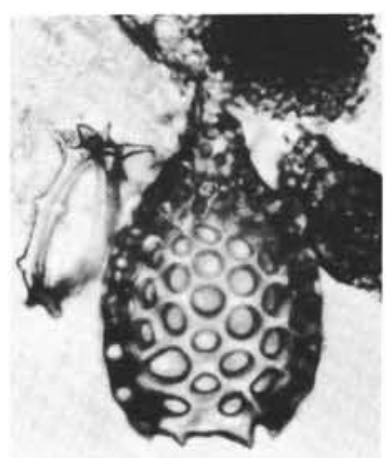

15
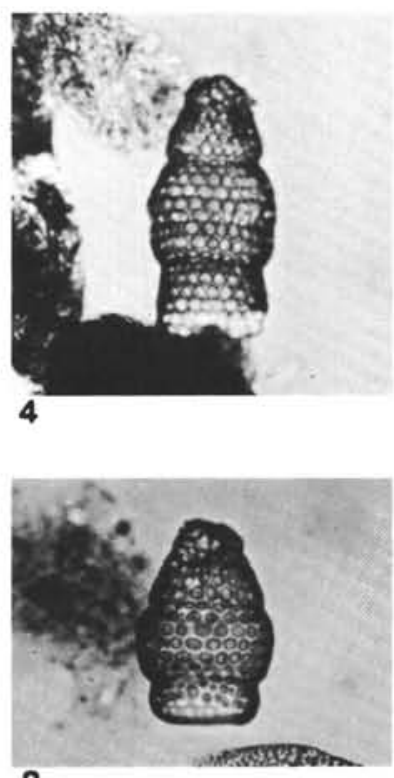

8

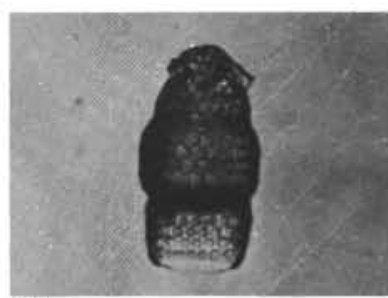

12

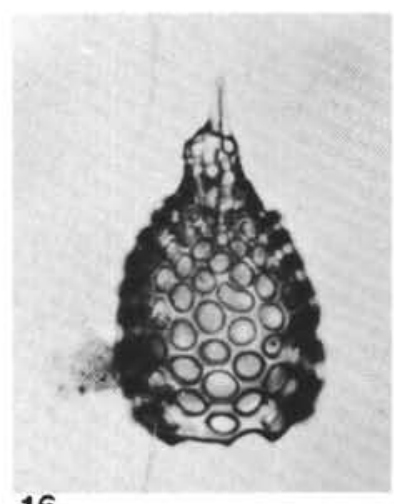

16

Plate 3. (Figs. 1-12 $\times 270$; Figs. 13-16 ×310.) 1, 2. Phormostichoartus(?) fistula, (1) Sample 594-52-2, 84-86 cm; (2) Sample 594-30-4, 84$86 \mathrm{~cm} .3,4,9,10,12$. Phormostichoartus pitomorphus, (3) Sample "Valdivia" 62; (4) Sample 594-9-4, 84-86 cm; (9) Sample 586B-8-3, 60$62 \mathrm{~cm}$, (10) Sample MD 75072-VIII-60 cm; (12) holotype, Sample MD 75072-VI-100 cm. 5, 6. Phormostichoartus platycephala, (5) Messinian, Spain, Sample 76285; (6) Sample MD 75072-IX-100 cm. 7, 8, 11. Phormostichoartus pitomorphus-P. platycephala, (7) Sample MD 83502-V$45 \mathrm{~cm}$; (8) Sample MD 75075-X-48 cm; (11) Sample MD 75075-IX-140 cm. 13-16. Lamprocyrtis daniellae, (13) Sample 586B-15-3, 60-62 cm; (14) holotype, Sample 586B-16-1, 60-62 cm, (15) Sample 586B-16-1, 60-62 cm; (16) Sample 586B-16-1, 60-62 cm. 


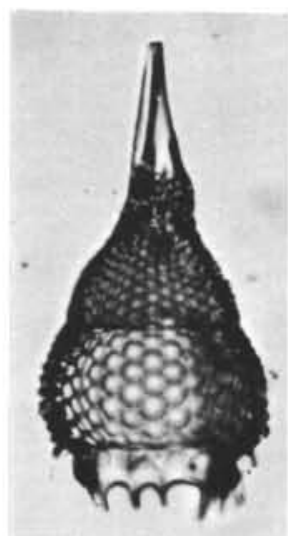

1

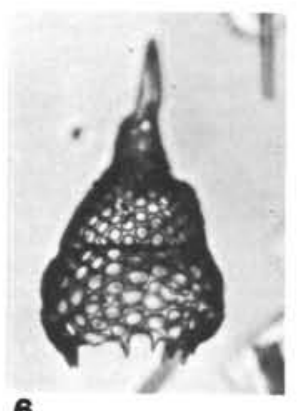

6

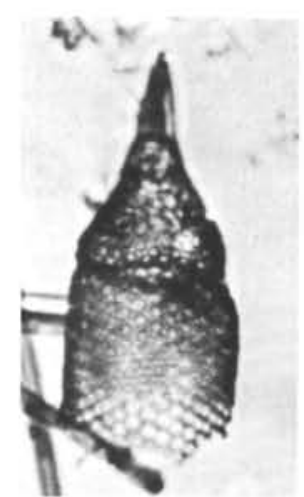

11

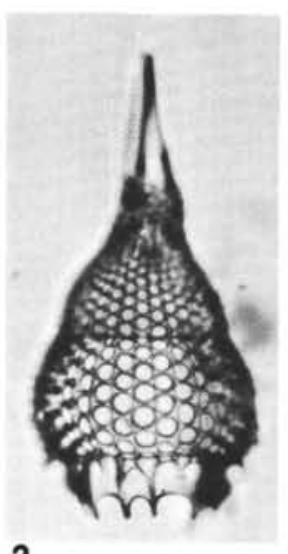

2

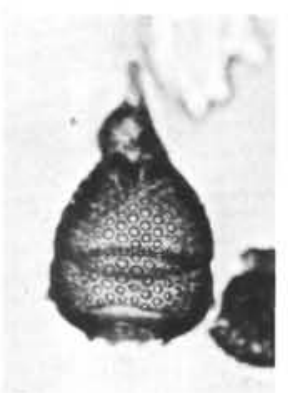

7

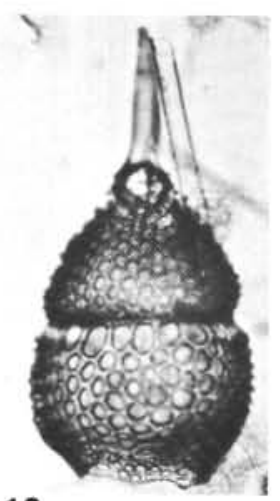

12

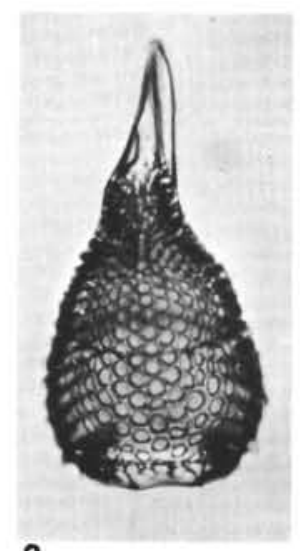

3

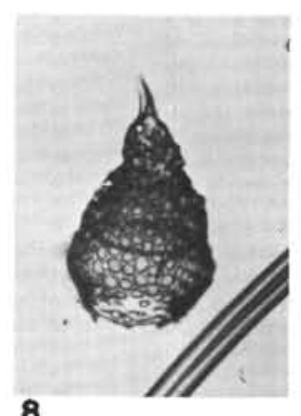

8

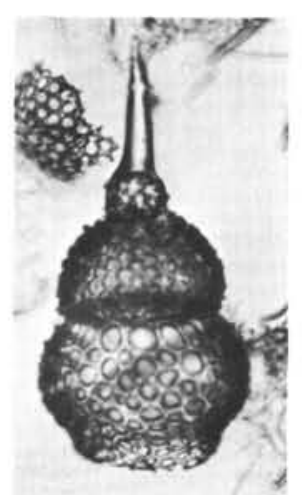

13

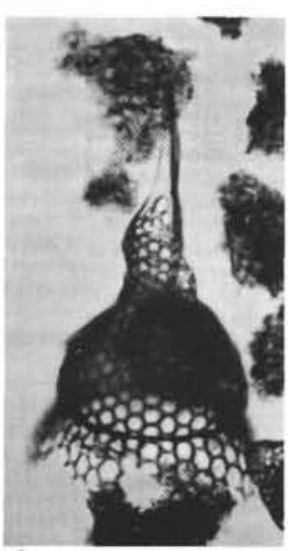

4

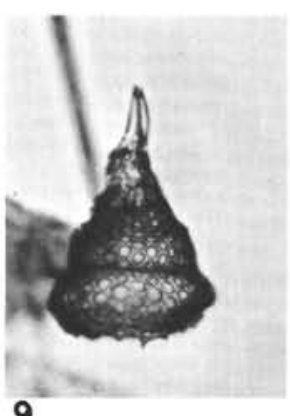

9

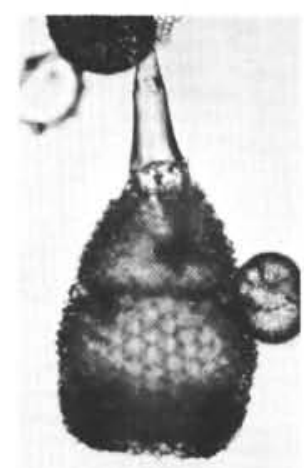

14

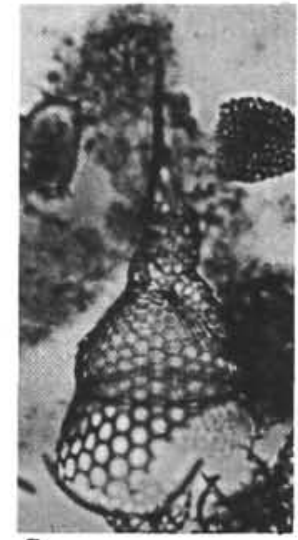

5

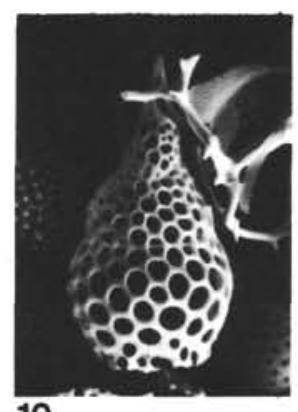

10

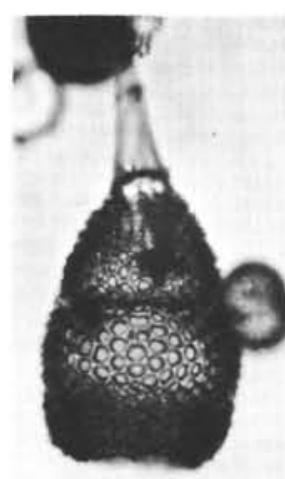

15

Plate 4. (Figs. 1-10 × 230.) 1, 2. Lamprocyclas aff. maritalis, (1) Sample 594-29-4, 84-86 cm; (2) Sample 594-29-4, 84-86 cm. 3. Lamprocyclas margatensis, Sample 586B-16-3, 60-62 cm. 4, 5. Pterocorys longicollis, (4) holotype, Sample 586B-6-2, 60-62 cm; (5) Sample 586B-6-2, 60$62 \mathrm{~cm}$. 6. Lamprocyclas sp., Sample 594-41-2, 84-86 cm. 7. Lamprocyclas sp., Sample 594-52-2, 84-86 cm. 8. Lamprocyclas sp., Sample 594-29-4, 84-86 cm. 9. Lamprocyclas sp., Sample 594-30-4, 84-86 cm. 10. Lamprocyclas junonis, Sample "Valdivia" 62.11. Pterocorys sp., Sample 592-40-2, 40-42 cm; $\times 300$. 12, 13. ? Lophocyrtis sp., Sample $592-40-1,40-42 \mathrm{~cm} ; \times 200.14,15$. ?Thyrsocyrtis sp., Sample $592-$ $39-3,40-42 \mathrm{~cm} ; \times 100$. 


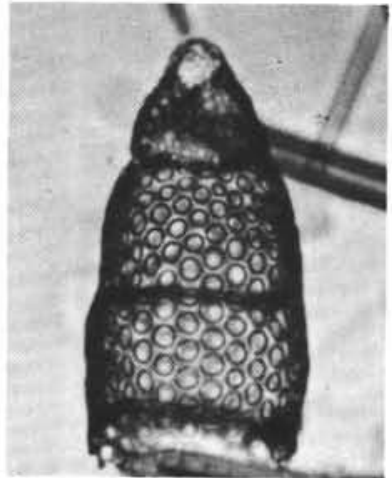

1
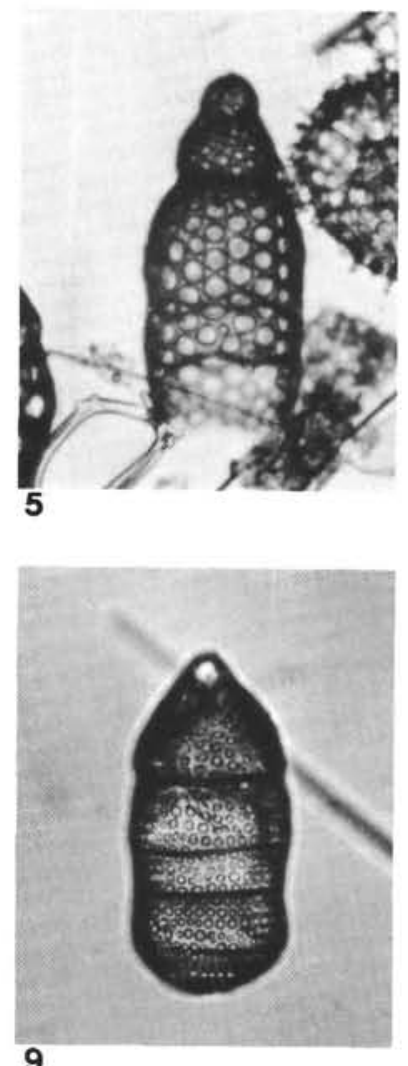

9

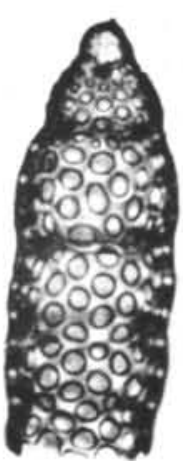

2
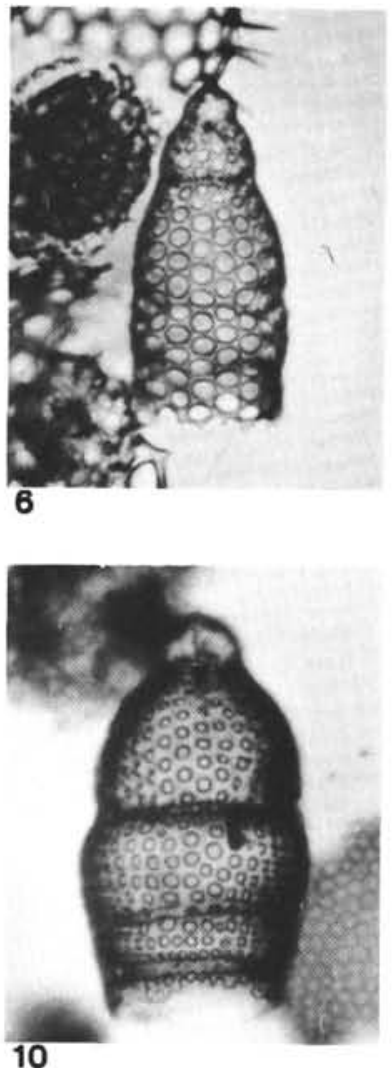

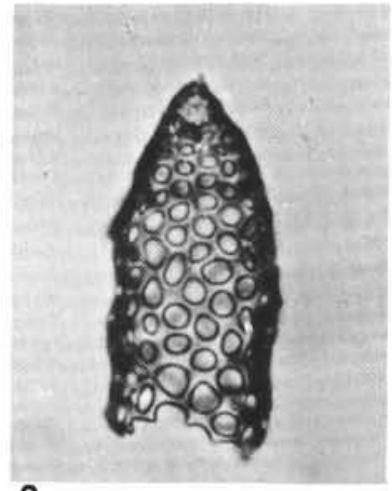

3
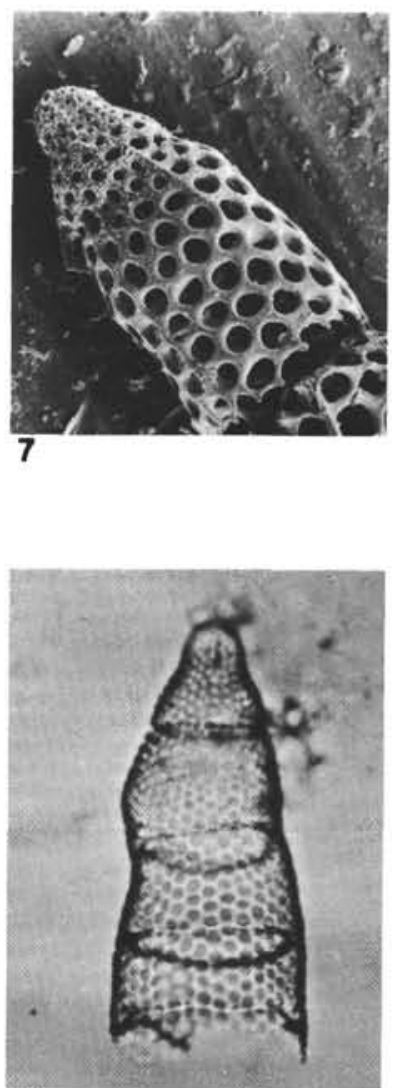

11

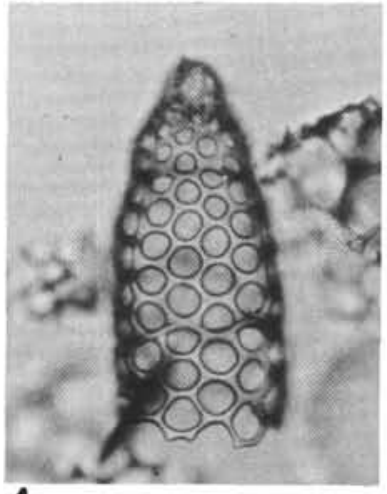

4
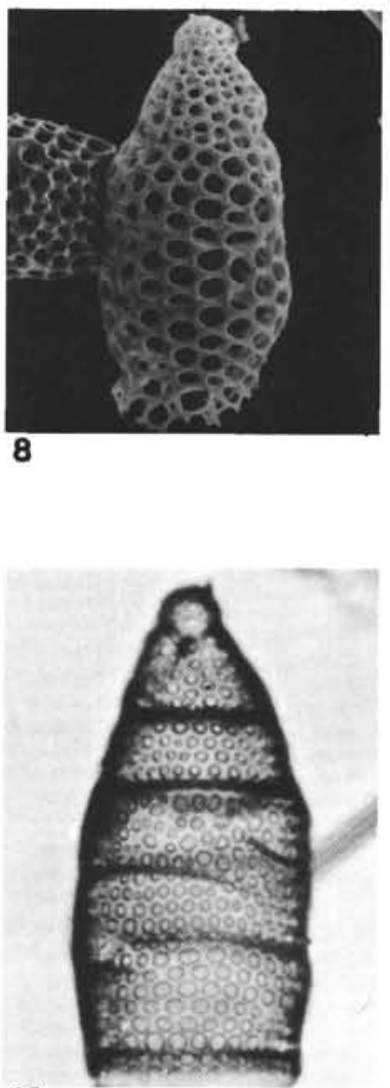

12

Plate 5. (All Figures $\times 380$.) 1-3. Eucyrtidium ? teuscheri gr., (1) Sample 594-52-1, 84-86 cm; (2) Sample 594-41-2, 84-86 cm; (3) Sample 2526-3, 20-21 cm. 4. Eucyrtidium teuscheri orthoporus, holotype, Sample MD $73028-\mathrm{II}-30 \mathrm{~cm}$. 5-8. Eucyrtidium teuscheri teuscheri, (5) Sample MD 75072-VIII-111 cm; (6) holotype, Sample MD 75071-V-100 cm; (7) Sample MD 75072-IX-100 cm; (8) Sample MD $75072-I I-60 \mathrm{~cm}$. 9. Eucyrtidium punctatum, Sample MD AET $75002-70 \mathrm{~cm}$. 10. Eucyrtidium anniae, holotype, Sample 594-31-4, 84-86 cm. 11. Eucyrtidium indiensis, Sample 586B-15-1, 60-62 cm. 12. Eucyrtidium sp., Sample 594-38-1, 84-86 cm. 


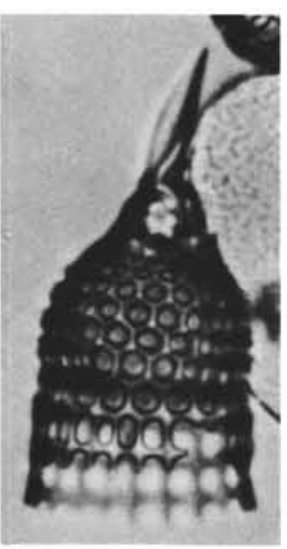

1

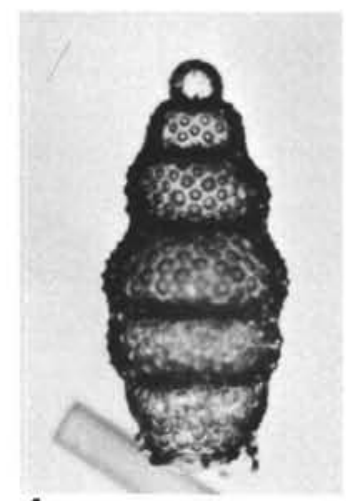

4

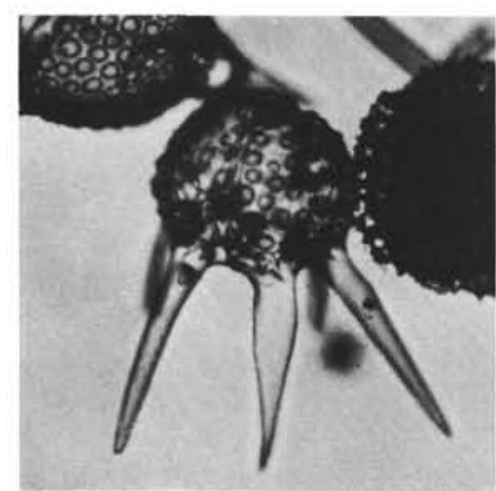

8

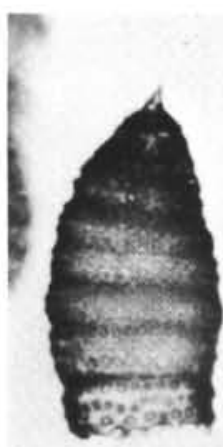

2

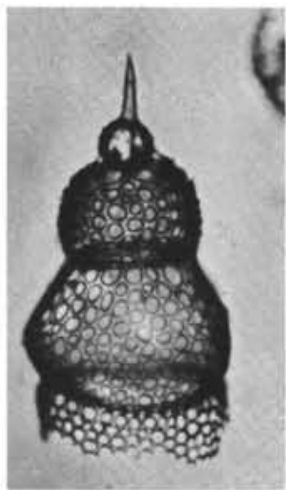

5

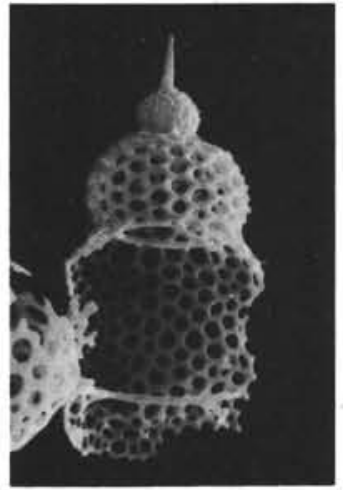

6

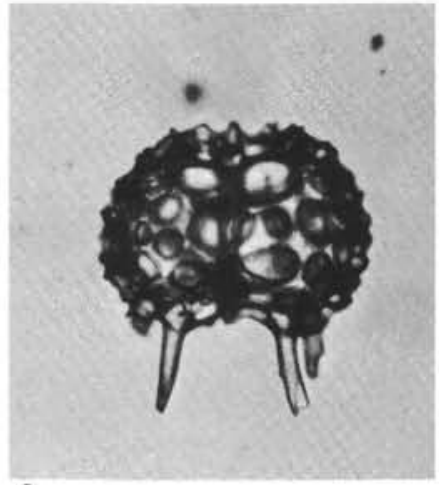

9

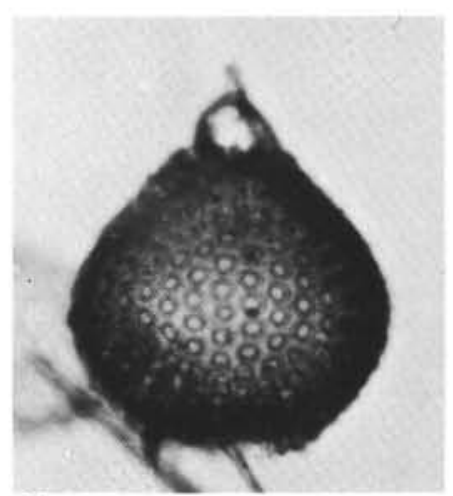

3

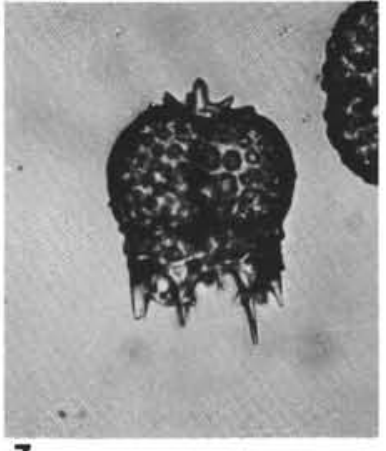

7

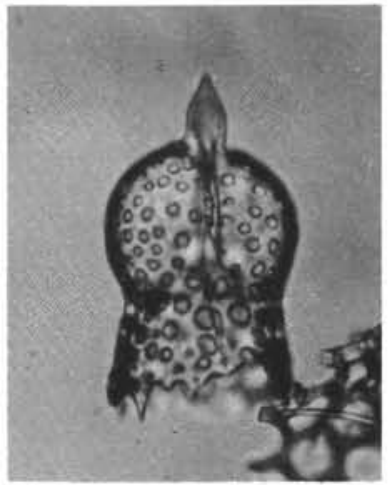

10

Plate 6. 1. Clathrocyclas sp., Sample 592-39-3, 40-42 cm; $\times 450$. 2. Botryostrobus sp., Sample 594-48-2, 84-86 cm; $\times 530$. 3. ?Theocorys sp., Sample 592-39-3, 40-42 cm; $\times 270$. 4. Stichocorys peregrina, Sample 594-24-4, 84-86 cm; $\times 400$. 5, 6. Stichocorys johnsoni, (5) holotype, Sample 586B-20-5, 60-62 cm; $\times$ 400; (6) Sample MD 77157-VI-20 cm; $\times 400 . \quad 7-10$. Acanthodesmiidae gen. et sp. indet., Sample 592-39-3, 40$42 \mathrm{~cm} ; \times 350$. 